\title{
Phytoplankton distribution in unusually low sea ice cover over the Pacific Arctic
}

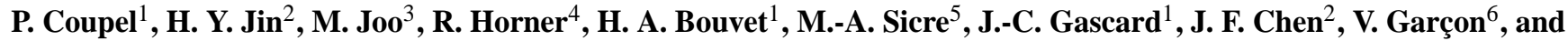 \\ D. Ruiz-Pino ${ }^{1}$ \\ ${ }^{1}$ Laboratoire d'Océanographie et du Climat: Expérimentation et Approches Numériques (LOCEAN), \\ UPMC, CNRS, UMR7159, Paris, France \\ ${ }^{2}$ Laboratory of Marine Ecosystem and Biogeochemistry, Second Institute of Oceanography, \\ SOA, PRC, Hangzhou 310012, China \\ ${ }^{3}$ Department of Oceanography, Pusan National University, 30, Jangjeon-dong, \\ Busan 609-735, South Korea \\ ${ }^{4}$ School of Oceanography, University of Washington, 373 Marine Science Building, \\ P.O. Box 357940, Seattle, WA, USA \\ ${ }^{5}$ Laboratoire des Sciences du Climat et de l'Environnement (LSCE), IPSL, CNRS/CEA/UVSQ, \\ 91198 Gif-sur-Yvette, France \\ ${ }^{6}$ LEGOS/UMR5566/CNRS, 18 Avenue Edouard Belin, 31401 Toulouse Cedex 4, France
}

Correspondence to: P. Coupel (pclod@locean-ipsl.upmc.fr)

Received: 19 January 2012 - Published in Biogeosciences Discuss.: 22 February 2012

Revised: 5 October 2012 - Accepted: 2 November 2012 - Published: 26 November 2012

\begin{abstract}
A large part of the Pacific Arctic basin experiences ice-free conditions in summer as a result of sea ice cover steadily decreasing over the last decades. To evaluate the impact of sea ice retreat on the marine ecosystem, phytoplankton in situ observations were acquired over the Chukchi shelf and the Canadian basin in 2008, a year of high melting. Pigment analyses and taxonomy enumerations were used to characterise the distribution of main phytoplanktonic groups. Marked spatial variability of the phytoplankton distribution was observed in summer 2008. Comparison of eight phytoplankton functional groups and 3 sizeclasses (pico-, nano- and micro-phytoplankton) also showed significant differences in abundance, biomass and distribution between summer of low ice cover (2008) and heavy ice summer (1994). Environmental parameters such as freshening, stratification, light and nutrient availability are discussed as possible causes to explain the observed differences in phytoplankton community structure between 1994 and 2008.
\end{abstract}

\section{Introduction}

The Arctic Ocean is experiencing the fastest environmental changes, which are likely related to increasing $\mathrm{CO}_{2}$ concentrations in the atmosphere. Both sea ice extent $(10 \%$ decrease per decade for 1979-2006; Comiso et al., 2008; Poliakov et al., 2010) and thickness (Kwok and Rothrock, 2009) have shown dramatic decreases in the recent years, reaching lowest values in 2007 and 2011 (Perovich, 2011). Simultaneously, river discharge increased (Peterson et al., 2006) leading to freshwater accumulation in the upper layer of the Arctic Ocean (Rabe et al., 2011), especially in the Canadian Basin. Environmental parameters driving phytoplankton growth and bloom occurrence such as light, stratification, temperature, freshening and nutrient availability have, thus, been modified with probable consequences on phytoplankton (Grebmeier, 2010; Wassmann et al., 2010).

Contradictory hypotheses have been proposed to explain the phytoplankton response to ice withdrawal. Increased primary production (PP) and total phytoplankton biomass in marginal Arctic seas is suggested by mathematical models (Zhang et al., 2010; Slagstad et al., 2011) and in situ data 


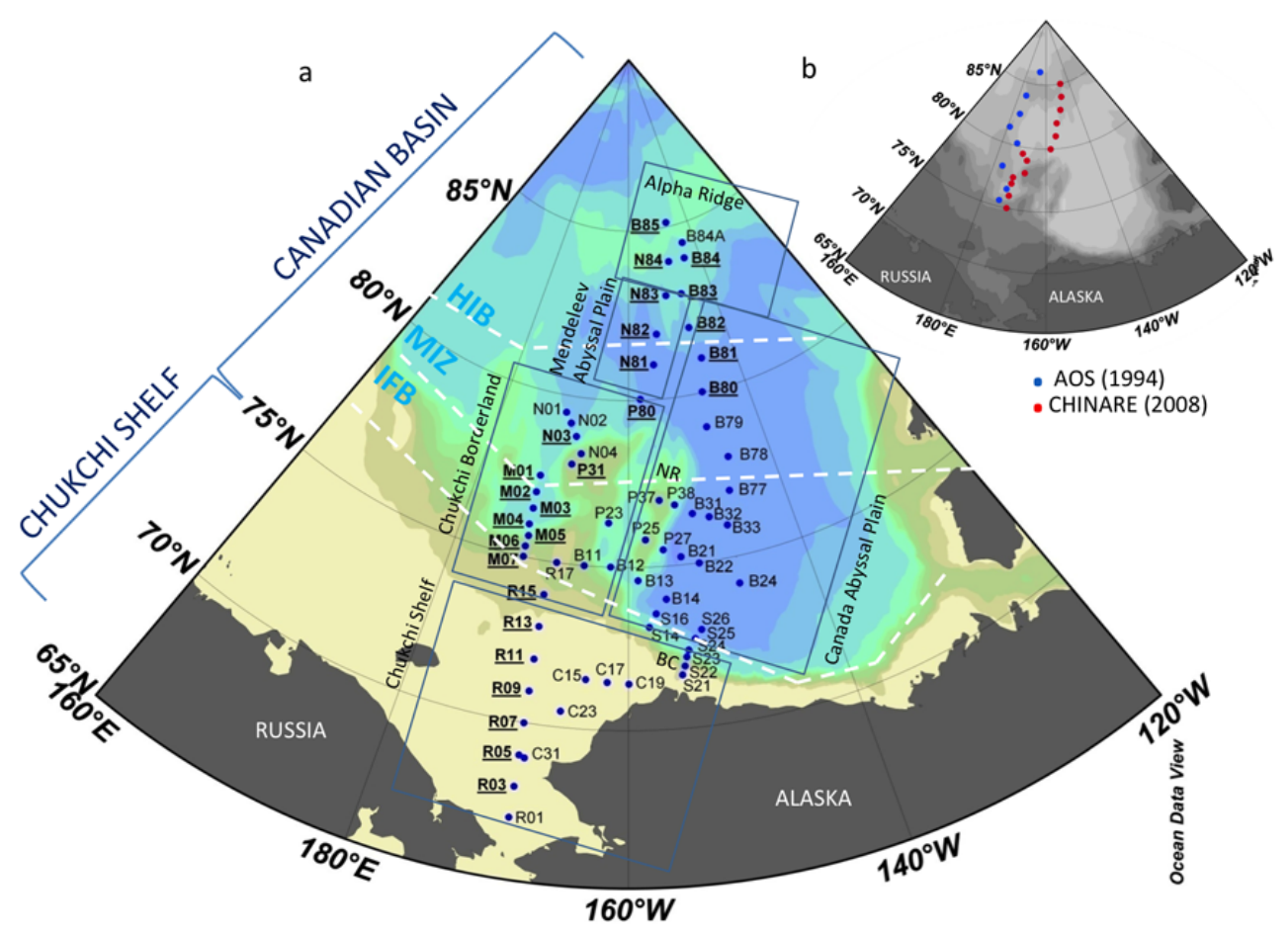

Fig. 1. (a) Sampling stations during the R/V CHINARE 2008 cruise performed onboard the R/V XueLong icebreaker (1 August-8 September 2008). Blue dots indicate stations where pigments were measured. Bold and underlined stations numbers indicate the stations where taxonomy data are available. The study area covered the shallow Chukchi shelf $(<100 \mathrm{~m})$ and the deep Canadian basin $(100$ to $4000 \mathrm{~m})$. The Canadian basin included the Canada Abyssal Plain, the Alpha Ridge, the Mendeleev Abyssal Plain and the Chukchi Borderland. The Barrow Canyon (BC) and the Northwind Ridge (NR) are indicated. Three areas are distinguished over the basin based on ice concentrations: the ice-free basins IFB (ice $<20 \%$ ), the marginal ice zone MIZ $(20 \%<$ ice $<70 \%)$ and the heavy-ice basin HIB (ice $<70 \%$ ). (b) Location of the stations sampled in 1994 (blue) and 2008 (red) used for comparison, discussed in the Sect. 4.2.

from the Beaufort (Carmack and Chapman, 2003; Lee and Whitledge, 2005), Barents and Greenland seas (Rysgaard et al., 1999). Satellite observations also suggested increased PP in the Arctic basin as a result of deeper light penetration and a longer phytoplankton growth season (Arrigo et al., 2008; Pabi et al., 2008). Higher PP could also result from higher nutrient availability fed by wind-driven upwellings (Carmack et al., 2004; Yang et al., 2004), favouring the development of larger taxa such as diatoms (Babin et al., 2004). On the contrary, recent studies reported no PP increase in ice-free waters of the Canadian basin due to water column stratification restraining nutrient availability (Sundfjord et al., 2008; Lee et al., 2011; Joo et al., 2011). Li et al. (2009) documented a shift towards smaller sized phytoplankton. A northward displacement of sub-Arctic species such as coccolithophores in the Barents Sea (Hegseth and Sundfjord, 2008) and unprecedented recent blooms of the coccolithophorid Emiliania huxleyi have been observed and linked to changing climates regimes, including decreased mixed layer depth and increased surface temperature (Napp and Hunt, 2001). In the Ross Sea, deeper mixed layer would have favoured haptophyte Phaeocystis sp. growth, while shallower mixed layer along melting ice edges promoted diatom blooms (Arrigo et al., 1999). Finally, microbial DNA analyses pointed out a decrease of the bacterial communities during the 2007 minimum sea ice extent (Comeau et al., 2011), while ciliates became more common and stramenopiles less numerous.

Yet, the scarcity of data on Arctic phytoplankton strongly limits our understanding of the impact of ice melting on primary producers. Moreover, most of available phytoplankton observations are from shelf areas, i.e., the Barents and Chukchi Seas (Carmack and Wassmann, 2006; Grebmeier et al., 2006; Wassmann, 2006) and few of them relate to deep basins (Wassmann et al., 2010; Poulin et al., 2011). Better assessment of phytoplankton changes induced by ice melting at a regional scale is critical because of their consequences on carbon fixation and export to the deep sea (Sigman and Boyle, 2000), which ultimately affect the $\mathrm{CO}_{2}$ Arctic sink (Bates et al., 2006; Anderson et al., 2010; Cai et al., 2010). In this study, we report on the phytoplankton distribution in the Pacific Arctic and discuss their link to environmental parameters during 2008, a year of unusually low sea ice cover, compared with a high-ice year (1994). 
Table 1. List of the pigments and their taxonomic significance (Wright and Jeffrey, 1997). The name of the twelve pigments used in CHEMTAX to distinguish between the eight phytoplankton classes are highlighted in bold. P: Picoplankton $(<2 \mu \mathrm{m}), \mathrm{N}$ : Nanoplankton $(2-20 \mu \mathrm{m})$,

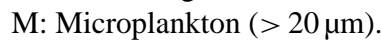

\begin{tabular}{llll}
\hline Pigments & Abbreviation & Size Classes & Taxonomic significance \\
\hline Fucoxanthin & Fuco & $\mathrm{M}$ & Diatoms, prymnesiophytes, some Dinoflagellates \\
Peridinin & Peri & $\mathrm{M}$ & Dinoflagellates \\
$\mathbf{1 9}^{\prime}$-Hexanoyloxyfucoxanthin & Hex & $\mathrm{N}$ & Prymnesiophytes \\
$\mathbf{1 9}^{\prime}$-Butanoyloxyfucoxanthin & But & $\mathrm{N}$ & Chrysophytes, Haptophytes \\
Chlorophyll $c$ 3 & Chl $c 3$ & $\mathrm{~N}$ & Prymnesiophytes, Chrysophytes \\
Alloxanthin & Allo & $\mathrm{N}$ & Cryptophytes \\
Prasinoxanthin & Pras & $\mathrm{P}$ & Prasinophytes \\
Neoxanthin & Neo & $\mathrm{P}$ & Chlorophytes, Prasinophytes \\
Chlorophyll $b$ & Chl $b$ & $\mathrm{P}$ & Chlorophytes, Prasinophytes \\
Violaxanthin & Viola & $\mathrm{P}$ & Chlorophytes, Prasinophytes \\
Lutein & Lut & $\mathrm{P}$ & Chlorophytes, Prasinophytes \\
Zeaxanthin & Zea & $\mathrm{P}$ & Cyanobacteria, Prochlorophytes, Chlorophytes, Chrysophytes \\
Divinyl Chlorophyll $a$ & Dvchla & $\mathrm{P}$ & Prochlorophytes \\
Chlorophyll $c 2$ & Chl $c 2$ & All & Various \\
Diadinoxanthin & Diadino & All & Various \\
Diatoxanthin & Diato & All & Various \\
$\beta$-Carotenes & Car & All & Various \\
Chlorophyll $a$ & Chl $a$ & - & All - except Prochlorophytes \\
\hline
\end{tabular}

\section{Methods}

\subsection{Study area and environmental parameters}

The R/V CHINARE 2008 oceanographic cruise was conducted onboard the Chinese icebreaker R/V Xuelong (Ice Dragoon) in late summer 2008 from 1 August to 8 September in the Pacific Arctic Ocean from latitudes 65 to $86^{\circ} \mathrm{N}$ (Fig. 1a). The study area covered the shallow Chukchi shelf $(<100 \mathrm{~m})$ south of $74^{\circ} \mathrm{N}$ and the deep Canadian basin $(100$ to $4000 \mathrm{~m}$ ) north of $74^{\circ} \mathrm{N}$. Regions visited over the Canadian basin included the Canada Abyssal Plain, the Alpha Ridge, the Mendeleev Abyssal Plain (MAP) and the Chukchi Borderland.

To investigate the role of the environmental conditions on the phytoplankton growth and distribution, several indexes were calculated. Daily ice concentrations (\%) were derived from the Special Sensor Microwave Imager (SSM/I) satellite data (level 2 products at $12.5 \mathrm{~km}$ spatial resolution). Temperature and salinity were acquired with a conductivitytemperature-depth system (CTD, Sea-Bird SBE 9). The euphotic depth (in $\mathrm{m}$ ) was provided by two methods: ocean color satellite MODIS (http://oceancolor.gsfc.nasa.gov/) and PAR attenuation calculated at different depth from in situ measurements (Zhao et al., 2010). The stratification of the upper layer $(100 \mathrm{~m})$ was estimated by the stratification index (SI), in kilograms per cubic metre $\left(\mathrm{kg} \mathrm{m}^{-3}\right)$, defined as the density difference between the surface and $100 \mathrm{~m}$ depth. The amount of freshwater from meltwater and river discharges accumulated in the surface layer was quantified by the surface fresh layer (SFL), defined as the thickness (in $\mathrm{m}$ ) of the layer above the isohaline 31 . The reference value $S=31$ was chosen to account for the impact of sea ice meltwater $(S=4)$ and rivers $(S=0)$ and exclude freshening due to the Pacific waters whose minimum salinity is 31 (Woodgate et al., 2005).

At each station, nutrient concentrations were determined at four to ten depths from the surface to the bottom of the ocean and determined onboard using the $\mathrm{Scan}^{++}$Continuous Flow Analyser (SKALAR). Nitrate $\left(\mathrm{NO}_{3}^{-}\right)$concentrations were measured using the method described by Wood et al. (1967) following the World Ocean Circulation Experiment (WOCE) protocol (Gordon et al., 1993) for the preparation of primary standards and reagents. The accuracy of the analytical system for nitrate concentrations in water samples is $\pm 0.1 \mu \mathrm{m}$. In the water column, the nitracline depth was determined by the position of the inflection point of the nitrate concentration profile. This nutrient is considered as the most limiting in Arctic waters (Trembay et al., 2006; Tremblay and Gagnon, 2009).

\subsection{Phytoplankton}

The phytoplankton distribution was determined by two methods: pigments analysed by high-performance liquid chromatography (HPLC, Jeffrey and Vesk, 1997) and microscopic enumerations of individual species. Until now, crosscomparison of pigments and taxonomy has not been undertaken in Arctic waters. The confrontation of these two methods provides a robust approach to fully describe the phytoplankton distribution in the Arctic Ocean. Light microscopy allows the identification of phytoplankton communities at the 


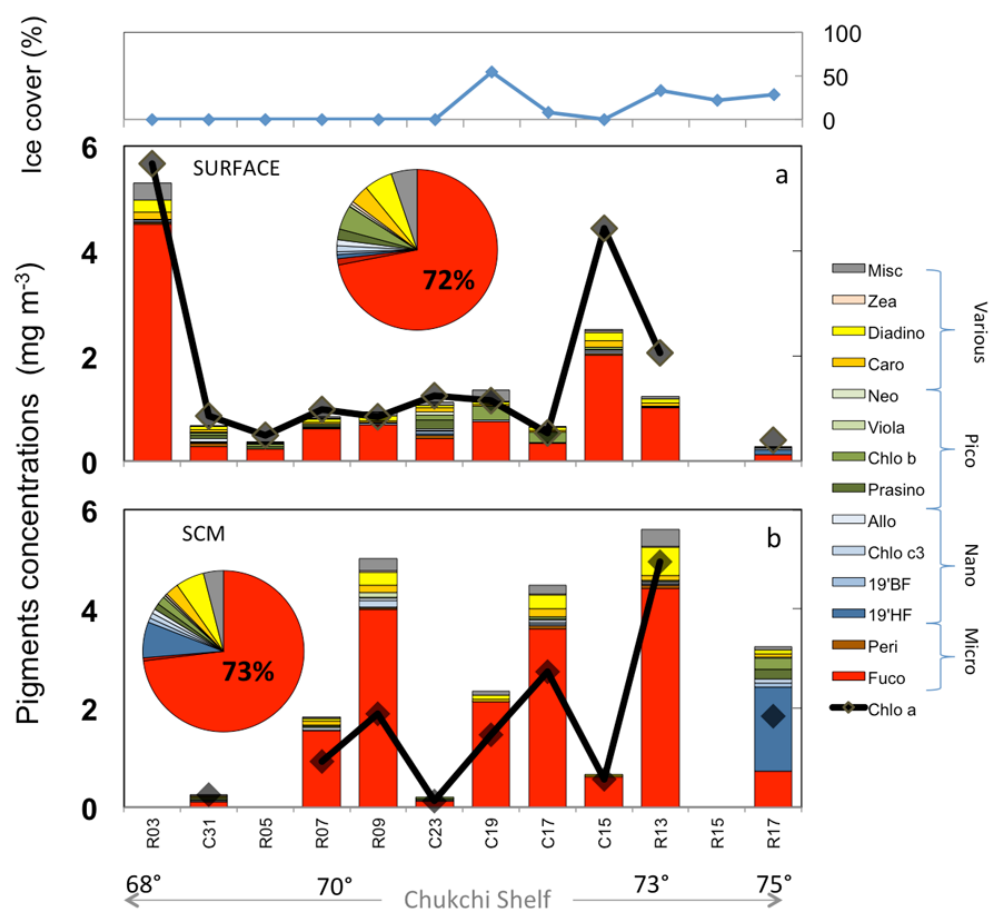

Fig. 2. Concentrations of Chlorophyll $a\left(\mathrm{Chl} a\right.$ ) and major accessory phytoplankton pigments (in $\mathrm{mg} \mathrm{m}^{-3}$ ) (see Table 1 for pigment acronyms) over the Chukchi Shelf in (a) surface waters and (b) in the SCM. The miscellaneous group (Misc) refers to pigments present in proportions $<2 \%$, i.e., Chl $c 2$, Diato, Lut, DVchla. The pie charts show the mean relative proportions of the major accessory pigments.

scale of the species. Yet, this method is time-consuming and the absence of discernable features hampers the identification of small size phytoplankton. In contrast, the reproductivity and rapidity of the HPLC allow for the analysis of a large number of samples. Photosynthetic pigments allow recognition of the smaller fraction of phytoplankton thanks to distinctive suites of marker pigments (Jeffrey and Vesk, 1997). However, many pigments are shared among different algal classes (Jeffrey et al., 1999) which imply possible misinterpretation in determining phytoplankton composition.

\subsubsection{HPLC pigments}

Samples for pigment analyses were collected at 65 stations (Fig. 1a). For each station two depths were sampled, i.e., at $3 \mathrm{~m}$ and in the sub-surface chlorophyll maximum (SCM) assumed to be the depth of maximum biomass determined from the peak of fluorescence. About $2 \mathrm{~L}$ of seawater were filtered through $25 \mathrm{~mm}$ Whatman GF/F filters $(0.7 \mu \mathrm{m}$ porosity), then stored in a freezer at $-80^{\circ} \mathrm{C}$ to avoid biological degradation. HPLC analyses were performed in SOA (Second Institute of Oceanography, Hangzhou, China) following the method developed by Van Heukelem and Thomas (2001). Pigments were extracted $1 \mathrm{~h}$ at $-20^{\circ} \mathrm{C}$ in methanol and placed in an ultra-sonic bath to disrupt cells. An internal standard, the DL- $\alpha$ Tocopherol acetate, was added to the extraction solvent to correct pigment concentrations from recovery. Pigments were analysed using a Waters 600E HPLC and an
Eclipse C8 column $(150 \times 4.6 \mathrm{~mm}, 3.5 \mu \mathrm{m})$ thermostated at $60^{\circ} \mathrm{C}$ at a flow rate of $1 \mathrm{~m} \mathrm{~min}^{-1}$. Every 30 samples, a standard mixture was analysed under the same conditions to avoid from HPLC deviation. Chlorophyll $a(\mathrm{Chl} a)$ and 17 accessory pigments were quantified based on their retention time (Table 1). Twelve pigments (in bold in Table 1) were used to distinguish the relative contribution between eight phytoplankton classes (diatoms, dinoflagellates, chrysophytes, prymnesiophytes, cryptophytes, prasinophytes chlorophytes and cyanobacteria) using the matrix factorization programme CHEMTAX (CHEMical TAXonomy) running under MATLAB ${ }^{\mathrm{TM}}$ following Mackey et al. (1996) and using a conversion matrice ratios constructed for the southern polar ocean species by Wright et al. (1996). Pigments were gathered into three size classes: micro- $(>20 \mu \mathrm{m})$, nano- (2$20 \mu \mathrm{m})$ and picophytoplankton $(<2 \mu \mathrm{m})$, based on their major taxonomic significance in term of algal divisions and classes (Wright and Jeffrey, 1997). The micro-sized phytoplankton pigments include those produced by dinoflagellates and diatoms; nano-sized phytoplankton pigments are from prymnesiophytes, chrysophytes and cryptophytes and finally the pico-sized phytoplankton pigments comprise those synthesised by cyanobacteria, prochlorophytes, chlorophytes and prasinophytes. 


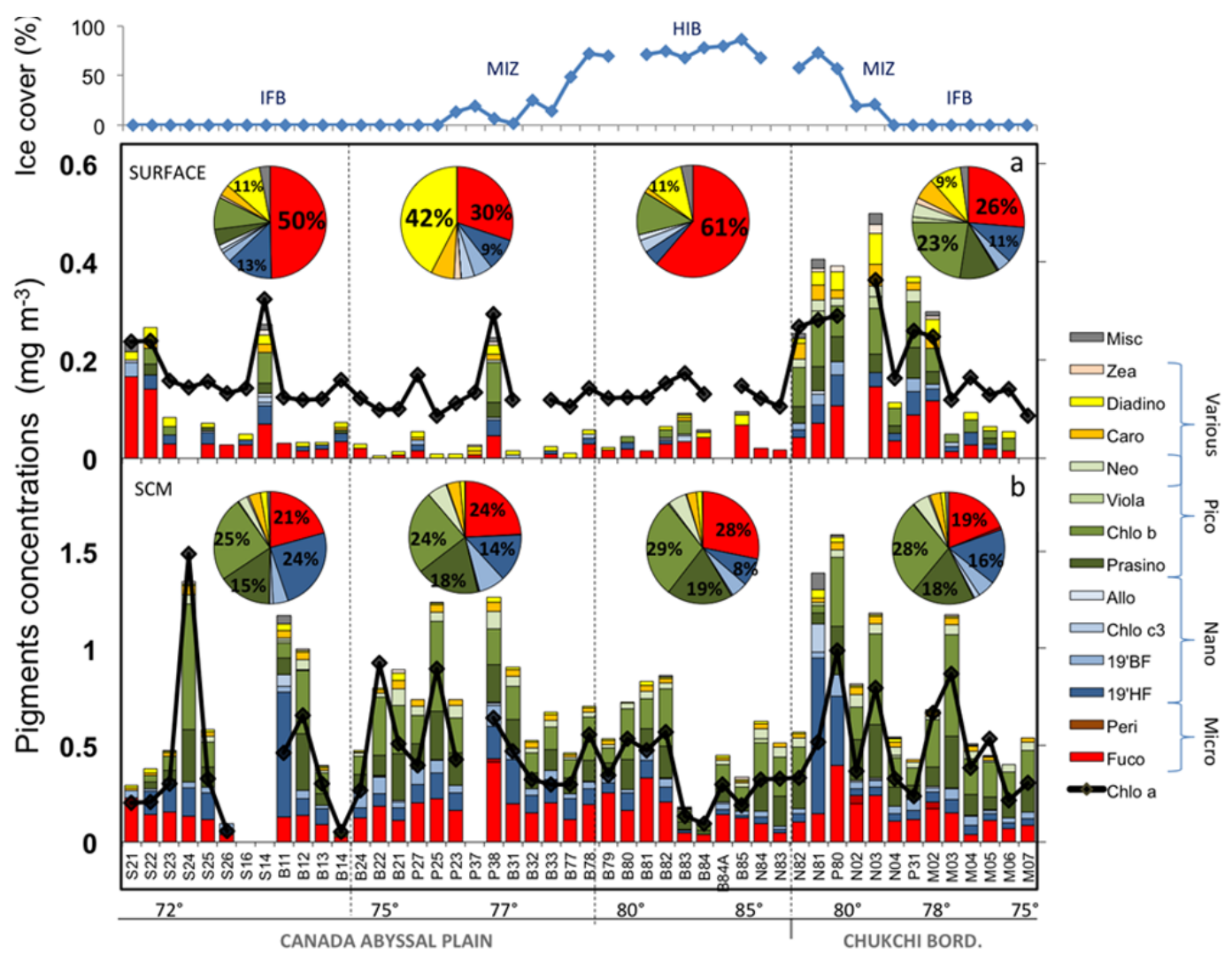

Fig. 3. Concentrations of Chlorophyll $a(\mathrm{Chl} a)$ and major accessory phytoplankton pigment concentrations (in $\mathrm{mg} \mathrm{m}^{-3}$ ) (Table 1 for pigment acronyms) over the Chukchi Borderland and the Canada Abyssal Plain in (a) surface waters and (b) in the SCM. The miscellaneous group (Misc) refers to pigments present in proportions $<2 \%$, i.e., Chl $c 2$, Diato, Lut, DVchla. The pie charts show the average relative proportions of the major accessory pigments.

\subsubsection{Light microscopy identification and counts of phytoplankton}

The 27 stations underlined in Fig. 1a were sampled for taxonomic enumerations at the same two depths as for pigment analysis (surface and SCM). About $100 \mathrm{ml}$ of water taken from Niskin bottles were used for microscopic identification and preserved with glutaraldehyde (final concentration $1 \%$ ) before filtration through Gelman GN-6 Metricel filters $(0.45 \mu \mathrm{m}$ pore size, $25 \mathrm{~mm}$ diameter). The filters were set up, onboard, on microscope slides with water-soluble embedding media (2-hydroxypropyl methacrylate). In the laboratory, the slides were used to identify and count phytoplankton species following the procedure of Joo et al. (2011). At least 300 cells were counted under the microscope (BX51, Olympus) with a combination of light and epifluorescence microscopy at 400 times for microplankton and at 1000 times for pico- and nanoplankton. The carbon biomass associated to each phytoplanktonic group was estimated from specific species biovolumes according to the equations of MendenDauer and Lessard (2000). These equations correspond to the more recent upgrade for biovolume calculations. Biovolume estimates of each species were based on cell dimensions measured by light microscopy using appropriate geometric shapes according to Sun and Liu (2003). As for the pigments, the phytoplankton species identified by microscopy were associated to three size classes. Micro-sized plankton includes diatoms and dinoflagellates. Unidentified nanoplankton, prymnesiophytes, dictyochophytes, chrysophytes and cryptophytes belong to nano-sized phytoplankton. Unidentified picoplankton and prasinophytes represent the pico-sized phytoplankton.

\section{Results}

\subsection{Ice cover and spatial distribution of phytoplankton communities}

Phytoplankton distribution at stations located in the shallow Chukchi shelf is described separately from those from the oligotrophic Canadian basin, because of significantly different pigments and taxonomic assemblages. Among the Canadian basin, three areas can be distinguished according to the ice conditions: (i) the southern part of the Canadian basin $\left(74-77^{\circ} \mathrm{N}\right)$ characterised by ice free condition (ice 

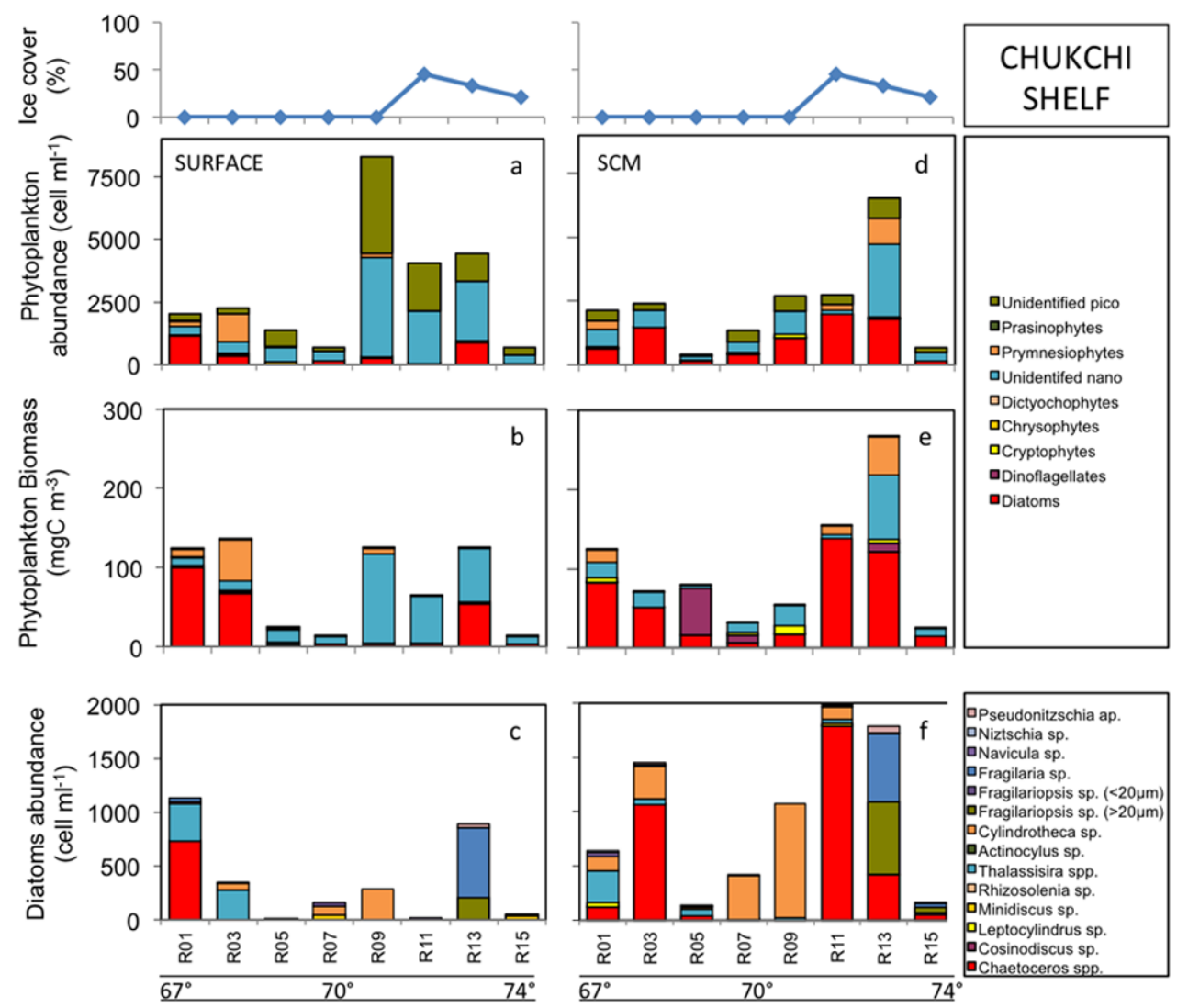

Fig. 4. Phytoplankton abundance and carbon biomass derived from microscopic counts in surface water (left panels) and in the SCM (right panels) over the Chukchi Shelf. The four upper panels show the abundance (a-d) and carbon biomass (b-e) of the major taxa. Two bottom panels (c-f) show the abundance of the 14 dominant centric and penate diatoms.

$<20 \%$ ) called the "ice-free basins" (IFB, Fig. 1a), (ii) the "marginal ice zone" (MIZ) over the Chukchi Borderland and the Canada Abyssal Plain associated with a partial ice cover (20-70\%), and (iii) the northern part of the basins called "heavy-ice basins" (HIB) where the ice cover was $>70 \%$, reaching exceptionally $90 \%$ or more at three stations north of $84^{\circ} \mathrm{N}$. For each province, the surface and SCM data were compared.

\subsubsection{Accessory pigments}

Chukchi shelf. Pigment distributions of the Chukchi shelf are not significantly different in surface and SCM waters except for the photoprotective pigment carotene (Caro), slightly higher in surface layers (Table 1 in Supplement). The average concentration of accessory pigments was three times higher at the SCM $\left(2.59 \pm 2.28 \mathrm{mg} \mathrm{m}^{-3}\right.$, Fig. $\left.2 b\right)$ than at the surface $\left(0.99 \pm 0.64 \mathrm{mg} \mathrm{m}^{-3}\right.$, Fig. 2a) and varied in parallel to Chl $a$ concentration $\left(r^{2}=0.93\right.$, Table 2 in Supplement). Pigment assemblage at both depth were largely dominated by fucoxanthin mainly produced by diatoms (Fuco $>70 \%$, Fig. 2a, b). Other pigments such as prasinoxanthin (Prasino), chlorophyll $b(\mathrm{Chl} b)$, diadinoxanthin (Diadino) and Caro accounted for 3 to $5 \%$ of the total pigment concentrations. The peridinin (Peri), primarily synthesized by dinoflagellates, represented less than $2 \%$ of the accessory pigments.

Lowest pigment concentrations were observed along the west coast of Alaska (St. C31, R05, C23, Fig. 2b). "While Fuco still prevailed in these areas (40\%), typical pigments of small-size species, such as Pras (10\%), Chl $b$ (10-30\%), neoxanthin (Neo $\sim 5 \%$ ) and alloxanthin (Allo $\sim 5 \%$ ) increased at both depths. Of note, the high concentrations of $19^{\prime}$-hexanoyloxyfucoxanthin (19HF, $1.69 \mathrm{mg} \mathrm{m}^{-3}$ ) found at $40 \mathrm{~m}$ depth in station R17, suggesting high concentrations of prymnesiophyte (coccolithophorids or Phaeocystis sp.).

Canadian basin. The Canadian basin waters show statistically different pigment assemblage than in shelf waters (Fig. 3, Table 1 in Supplement). The oligotrophic surface waters (Chl $a \sim 0.14 \pm 0.08 \mathrm{mg} \mathrm{m}^{-3}$, Fig. 3a) of the Canadian basin were dominated by Fuco and Diadino, while 19HF was the third major pigment accounting for $5 \%$ to $13 \%$ of the pigment assemblage. Total pigment concentrations were up to $6 \times$ higher at SCM (Fig. 3b) than in surface waters, with more 19BF, 19HF, Neo, Pras but less Diadino in relative proportion (Table 1 in Supplement). The Fuco, Chl $b$, Prasino and 19HF prevailed and accounted for $80 \%$ of the 

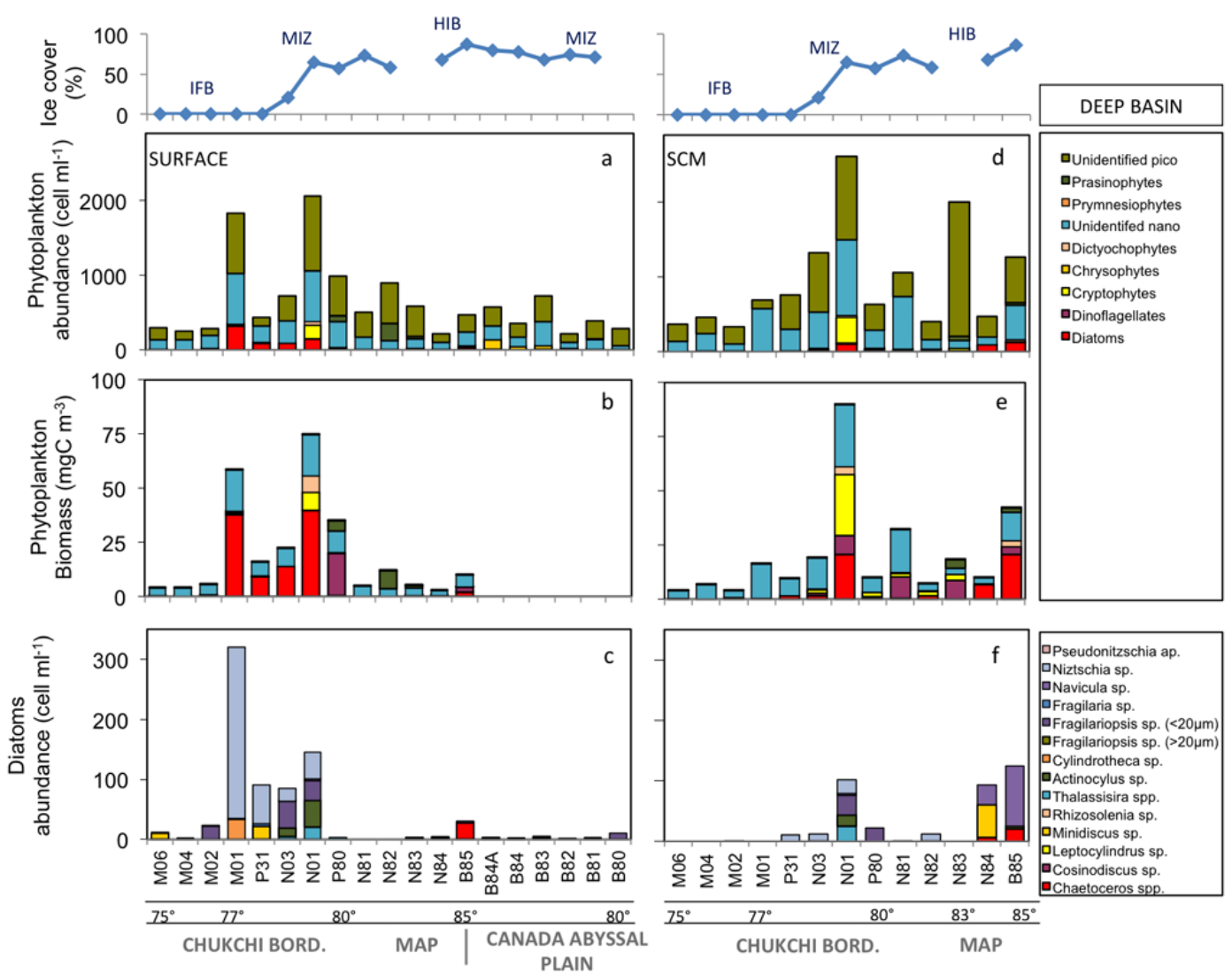

Fig. 5. Phytoplankton abundance and carbon biomass derived from microscopic counts in surface (left panels) and SCM (right panels) over the Chukchi Borderland, Mendeleev Abyssal Plain (MAP) and the Canada Abyssal Plain. The four upper panels show the abundance (a-d) and carbon biomass (b-e) of the major taxa. Two bottom panels (c-f) show the abundances of the 14 dominant centric and penate diatoms.

total accessory pigments at the SCM suggesting communities dominated by prasinophytes $(\mathrm{Chl} b+\operatorname{Pras}=40 \%)$, diatoms $($ Fuco $=25 \%)$ and prymnesiophytes $(19 \mathrm{HF}=15 \%)$. 19HF reached highest values at the SCM of two stations, B11 (continental slope) and N81 (Mendeleev Abyssal Plain). The 19BF, Neo and Diadino were detected at all stations but in concentrations $5 \times$ lower than the four major pigments mentioned above. Peri and divinyl chlorophyll $a$ (DV Chl $a$ ), produced by dinoflagellates and prochlorophytes, respectively, were absent from the Canadian basin. Relatively surface rich pigment waters $\left(0.2-0.5 \mathrm{mg} \mathrm{m}^{-3}\right.$, Fig. 3a) were found near Barrow Canyon $\left(72-73^{\circ} \mathrm{N}\right)$, at station P38 above the Northwind Ridge $\left(77^{\circ} \mathrm{N}\right)$, and in the MIZ over the north Chukchi Borderland $\left(78\right.$ to $\left.82^{\circ} \mathrm{N}\right)$ exhibiting similar pigment composition as in the SCM.

\subsubsection{Taxonomy}

Chukchi shelf. Highest surface and SCM cell abundances were encountered in the northern part of the Chukchi shelf $\left(71-73^{\circ} \mathrm{N}\right.$, Fig. $\left.4 \mathrm{a}, \mathrm{d}\right)$ partially ice covered (10 to $50 \%$, top of Fig. 4). Unidentified nanoplankton was dominant in abundance (52\%, Fig. 4a) and biomass (60\%, Fig. 4b) in the surface waters, while pennate diatoms Fragilaria sp. and Fragilariopsis sp. and the centric diatom Chaetoceros spp. (Fig. 4f) dominated the biomass at the SCM (56\%, Fig. 4e). In the southern shelf $\left(67-69^{\circ} \mathrm{N}\right)$, centric diatoms Chaetoceros spp. and Thalassiosira spp. and the prymnesiophyte Phaeocystis pouchetii prevailed both at the surface (Fig. 4b, c) and in the SCM (Fig. 4e, f). The central shelf $\left(69-70^{\circ} \mathrm{N}\right)$ had the lowest biomass mostly composed by the dinoflagellate Gymnodinium sp. (not shown) and the pennate diatom Cylindrotheca sp. in the SCM (Fig. 4e, f), and unidentified nanoplankton in surface waters (Fig. 4b). Unidentified picoplankton $(<2 \mu \mathrm{m})$ accounted for 36 and $16 \%$ of total cell abundances in surface (Fig. 4a) and SCM waters (Fig. 4d), respectively, and less than $1 \%$ of the total carbon biomass (Fig. 4b, d).

Canadian basin. Compared to the shelf, picoplankton abundances over the deep Canadian basin are higher by a factor two while nanoplankton and diatoms are lower by a factor 5 and 10, respectively (Table 2). Surface and SCM phytoplankton abundances were dominated by picoplankton $(55 \%)$ and nanoplankton (40\%), while diatoms amounted to only $5 \%$ of the cell number (Fig. 5a, d; Table 2). Conversely, diatoms and nanoplankton dominated the Canadian 


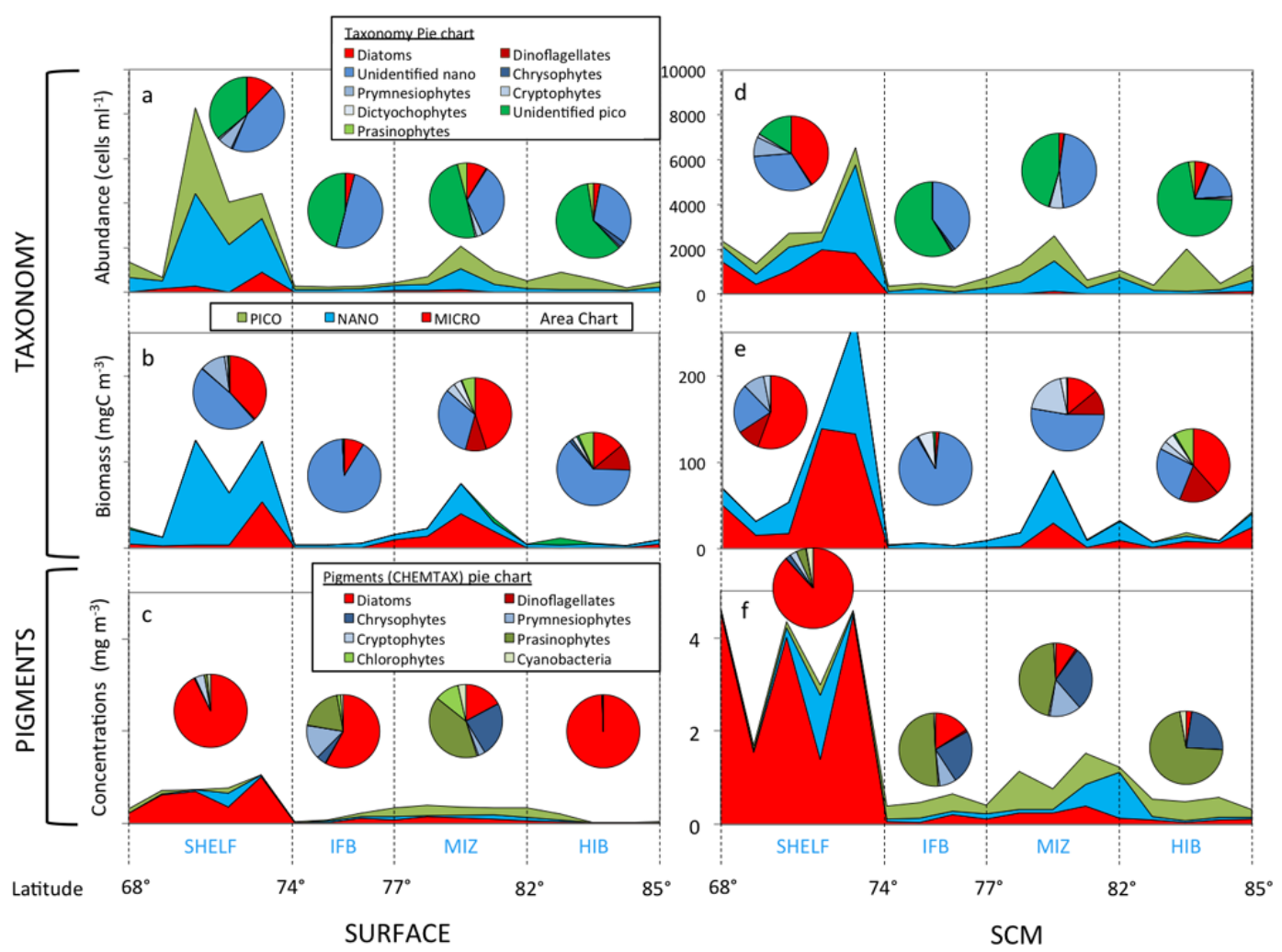

Fig. 6. Distribution of major groups of phytoplankton obtained by taxonomy (a, b, c, d) and pigments (e-f) in surface water (left panels) and in the SCM (right panels). Area charts show the abundance (a, b) and carbon biomass (c, d) of pico-, nano- and microplankton derived from taxonomy over the shelf, the ice-free basin (IFB), the marginal ice zone (MIZ) and heavy-ice basin (HIB). Area charts (e, f) show abundance of pico-, nano- and microplankton derived from pigment concentrations. Pie charts (a, b, c) and (d) show major phytoplankton groups derived from taxonomy counts. Pie charts (e) and (f) show the major phytoplankton groups calculated by the matrix factorization program CHEMTAX.

basin waters in term of carbon biomass while picoplankton accounted for only $5 \%$ (Fig. 5b, e; Table 2). Highest abundances and biomasses were found in the MIZ over the Chukchi Borderland $\left(77-80^{\circ} \mathrm{N}\right)$ near the surface $(5-20 \mathrm{~m})$ and were dominated by diatoms type Nitzschia sp. (290 cells $\mathrm{ml}^{-1}$, Fig. 5c), and to a lesser extent Fragilariopsis sp., Actinocyclus sp., and locally at greater depth by cryptophytes (St N01, Fig. 5e). In contrast, the IFB (75$\left.77^{\circ} \mathrm{N}\right)$ largely represented by nanoplankton $(90 \%)$ exhibited the lowest biomasses and abundances $\left(\sim 5 \mathrm{mgC} \mathrm{m}^{-3}\right.$, Fig. 5 and Table 2). Finally, phytoplankton biomasses over the HIB areas $\left(>80^{\circ} \mathrm{N}\right)$ were higher at SCM than surface waters and were dominated by nanoplankton, dinoflagellates type Gymnodinium sp. and Heterocapsa sp. between 80 and $83^{\circ} \mathrm{N}$ (Fig. 5b, e) and by the diatoms Minidiscus sp., Navicula sp. and Chaetoceros sp., north of $83^{\circ} \mathrm{N}$ (Fig. 5c, f). While the microplankton is well-identified by microscopy, the majority of the picoplankton and nanoplankton remained unidentified $(>90 \%)$. The few picoplankton cells identified were prasinophytes, type Micromonas sp., consistently with the observations published by Lovejoy et al. (2007) and for nanoplankton, the cryptophyte Cryptomonas sp. and the chrysophyte Dinobryon belgica, over the Alpha Ridge.

\section{Discussion}

\subsection{Significance and comparison of pigments and taxonomic counts}

R/V CHINARE 2008 uses two methods to characterise the phytoplankton distribution, i.e., pigments (HPLC) and taxonomy (microscopy), offering the possibility of crosscomparison and providing a useful test of the CHEMTAX algorithm for the Arctic Ocean. Pigments are useful indicators for offshore waters where more than $90 \%$ of the phytoplankton remains unidentified by microscopy. According to CHEMTAX, the picoplankton unidentified by cell counts (Fig. 6a, d) could be mainly prasinophytes (Fig. 6c, f), and unidentified nanoplankton could be chrysophytes and prymnesiophytes. Diatoms $\left(r^{2}=0.93\right)$ and cryptophytes $\left(r^{2}=\right.$ $0.61)$ pigments are correlated to their respective taxonomic abundances (Fig. 1a, b in the Supplement). Such correlation 
Table 2. Average abundances (cell $\left.\mathrm{ml}^{-1}\right)$, carbon biomass $\left(\mathrm{mgC} \mathrm{m}^{-3}\right)$ and relative contributions (\%) derived from CHEMTAX for 4 phytoplankton groups in surface and SCM waters.

\begin{tabular}{|c|c|c|c|c|c|}
\hline & $\begin{array}{r}\text { Diatoms } \\
(20-200 \mu \mathrm{m})\end{array}$ & $\begin{array}{r}\text { Dinoflagellates } \\
(10-100 \mu \mathrm{m})\end{array}$ & $\begin{array}{r}\text { Nanoplankton } \\
(2-20 \mu \mathrm{m})\end{array}$ & $\begin{array}{r}\text { Picoplankton } \\
(<2 \mu \mathrm{m})\end{array}$ & Total \\
\hline \multicolumn{6}{|l|}{ SURFACE } \\
\hline \multicolumn{6}{|c|}{ Abundance (cell ml ${ }^{-1}$} \\
\hline SHELF (68-74) & $362.0(12.2)$ & $0.2(0.0)$ & $1542.8(51.9)$ & $1068.6(35.9)$ & 2973.6 \\
\hline BASINS (68-86) & $32.9(4.9)$ & $2.0(0.3)$ & $245.9(36.6)$ & $390.5(58.2)$ & 671.3 \\
\hline IFB (75-77) & $11.3(4.1)$ & $0.0(0.0)$ & $139.4(50.0)$ & $128.0(45.9)$ & 278.7 \\
\hline MIZ (78-82) & $92.2(8.7)$ & $4.6(0.4)$ & $396.8(37.3)$ & $569.1(53.6)$ & 1062.6 \\
\hline HIB (83-86) & $12.3(2.9)$ & $0.2(0.0)$ & $148.8(35.0)$ & $263.4(62.0)$ & 424.6 \\
\hline \multicolumn{6}{|c|}{ Carbon biomass $\left(\mathrm{mgC} \mathrm{m}^{-3}\right.$} \\
\hline SHELF (68-74) & $29.4(37.8)$ & $0.4(0.5)$ & $47.2(60.7)$ & $0.7(0.8)$ & 77.7 \\
\hline BASINS (68-86) & $5.6(34.1)$ & $1.8(11.0)$ & $7.7(46.9)$ & $1.3(7.9)$ & 16.4 \\
\hline IFB (75-77) & $0.4(8.8)$ & $0.0(0.0)$ & $4.0(90.3)$ & $0.0(0.6)$ & 4.4 \\
\hline MIZ (78-82) & $14.4(45.0)$ & $3.0(9.3)$ & $12.6(39.5)$ & $2.0(6.3)$ & 32.0 \\
\hline HIB (83-86) & $0.8(13.9)$ & $0.7(11.5)$ & $4.1(66.8)$ & $0.5(7.6)$ & 6.1 \\
\hline CHEMTAX (\%) & & & & & Chl $a$ \\
\hline SHELF (68-74) & 92.6 & 0.0 & 4.6 & 2.8 & 1.19 \\
\hline BASINS (68-86) & 49.9 & 0.2 & 19.0 & 30.9 & 0.14 \\
\hline IFB (75-77) & 58.0 & 0.3 & 19.5 & 22.3 & 0.10 \\
\hline MIZ (78-82) & 17.2 & 0.1 & 27.8 & 54.9 & 0.21 \\
\hline HIB (83-86) & 99.4 & 0.2 & 0.2 & 0.3 & 0.04 \\
\hline \multicolumn{6}{|l|}{ SCM } \\
\hline \multicolumn{6}{|c|}{ Abundance (cell ml ${ }^{-1}$ ) } \\
\hline SHELF (68-74) & 959.4 (40.6) & $11.2(0.5)$ & $1009.6(42.7)$ & $385.5(16.3)$ & 2365.6 \\
\hline BASINS (68-86) & $31.6(3.2)$ & $3.6(3.7)$ & $377.2(38.7)$ & $561.5(57.6)$ & 974.0 \\
\hline IFB (75-77) & $0.4(0.1)$ & $0.0(0.0)$ & $160.4(41.4)$ & $226.8(58.5)$ & 387.6 \\
\hline MIZ (78-82) & $22.9(2.1)$ & $3.3(0.3)$ & $556.8(52.2)$ & $484.4(45.4)$ & 1067.4 \\
\hline HIB (83-86) & $72.7(5.8)$ & $6.7(0.5)$ & $240.1(19.2)$ & $929.1(74.4)$ & 1248.7 \\
\hline \multicolumn{6}{|c|}{ Carbon biomass ( $\mathrm{mgC} \mathrm{m}^{-3}$} \\
\hline SHELF (68-74) & $55.8(55.6)$ & $10.2(10.2)$ & $34.3(34.2)$ & $0.1(0.1)$ & 100.4 \\
\hline BASINS (68-86) & $4.5(21.3)$ & $2.7(12.8)$ & $13.3(63.0)$ & $0.6(2.8)$ & 21.1 \\
\hline IFB (75-77) & $0.1(1.6)$ & $0.0(0.0)$ & $4.7(97.3)$ & $0.0(1.0)$ & 4.9 \\
\hline MIZ (78-82) & $3.7(14.0)$ & $2.9(11.1)$ & $19.7(74.5)$ & $0.1(0.4)$ & 26.4 \\
\hline HIB (83-86) & $9.1(38.5)$ & $4.2(17.6)$ & $8.2(34.5)$ & $2.2(9.3)$ & 23.6 \\
\hline CHEMTAX (\%) & & & & & Chl $a$ \\
\hline SHELF (68-74) & 88.1 & 0.2 & 4.9 & 6.8 & 2.16 \\
\hline BASINS (68-86) & 10.8 & 0.7 & 35.1 & 53.4 & 0.50 \\
\hline IFB (75-77) & 15.9 & 0.9 & 32.1 & 51.1 & 0.69 \\
\hline MIZ (78-82) & 9.3 & 0.8 & 43.2 & 46.7 & 0.40 \\
\hline HIB (83-86) & 2.5 & 0.0 & 23.4 & 74.1 & 0.28 \\
\hline
\end{tabular}

In parenthesis are the given $\%$ abundance and $\%$ carbon biomass of the 4 phytoplanktonic groups for the different areas. Stations where taxonomic data are available were separated in Shelf and Basins. Basins are subdivided in three areas according to ice conditions: ice-free basins (IFB), marginal ice zone (MIZ) and the heavy ice basins (HIB). In the first column, the two numbers in parenthesis represent the range of latitude of each considered areas.

does not exist for the 4 others main phytoplankton groups (picoplankton, nanoplankton, dinoflagellates and prasinophytes, Fig. 1c, d, e, f in the Supplement). CHEMTAX seems to overestimate the diatom contribution and to minimise the importance of nanoplankton as compared to taxonomic observations (Table 2). For example, in shelf surface waters dominated by Fuco, CHEMTAX concludes to a large dominance of diatoms $(92.6 \%$, Fig. 6c) while taxonomic counts indicate dominant nanoplankton cell abundances $(51.9 \%$,
Fig. 6a) and carbon biomass (60.7\%, Fig. 6b). The systematic assignment of Fuco to diatoms by CHEMTAX, while this pigment is also a major pigment in nanoplankton like prymnesiophytes or dinoflagellates, may be responsible for this apparent discrepancy (Jeffrey et al., 1997; Rodriguez et al., 2002). In the Canadian basin and Chukchi shelf, pigments combined to cell counts suggest that Fuco is produced by nanoplankton rather than by diatoms. Similar conclusions have been achieved in the oligotrophic gyres of the 
subtropical Atlantic Ocean by Hirata et al. (2008). Furthermore, $\mathrm{Chl} b$ associated here to pico-sized prasinophytes has been attributed by Hirata et al. (2011) to nano-sized phytoplankton. While CHEMTAX reflects relatively well the phytoplankton abundance in Antarctic waters (Wright et al., 1996; Rodriguez et al., 2002), a calibration would improve its performance in Arctic waters.

Taxonomic data indicate that picoplankton $(<2 \mu \mathrm{m})$ accounted for $25 \%$ of the cell abundance, but contributed for less than $1 \%$ of the total phytoplankton carbon biomass over the shelf (Table 2). On the contrary, diatoms with a 1000 times larger biovolume than picoplankton contribute for a large part to the total carbon biomass over the Canadian basin, despite low cell numbers. The pigment cell content increases with depth in response to adaptation to low light availability (Henriksen et al., 2002). Pigment biomasses over the Canadian basin are 5 times higher in the deep SCM $(60 \mathrm{~m})$ than in surface (Fig. 6c, f), despite no significant increase of cells abundance (Fig. 6a, d and Table 2) and carbon biomass (Fig. 6b, e). Pearson test (Table 2, Supplement) indicate that $\mathrm{Chl} a$ better correlates with carbon biomass $(r=0.83)$ than cell abundances $(r=0.58)$ excepted for the SCM where Chl $a$ fit better with cell abundances than carbon biomass. No significant correlation was found between $\mathrm{Chl} a$ and the cell abundance or carbon biomass over the Canadian basin. Finally, low pigment concentrations in ultraoligotrophic surface waters of the IFB and HIB $(<0.05 \mathrm{mg}$ $\mathrm{Chl} a \mathrm{~m}^{-3}$ ) could hamper the detection of minor pigments by the HPLC. We estimated that a limit of detection for minor pigments occurs at total pigments concentration lower than $0.05 \mathrm{mg} \mathrm{m}^{-3}$.

The cross-comparison of pigments and taxonomic data highlight the different information provided by the two approaches to diagnose phytoplankton populations. Improvement of the relationship between taxonomic enumeration and pigment fingerprints would benefit from both additional field and in vitro experiments from the Arctic Ocean.

\subsection{Comparison with previous campaigns in Arctic Ocean}

Arctic main phytoplankton distribution differs widely between the marginal shelves and the deep central basins and depends strongly on sea ice conditions (Poulin et al., 2011). High biomasses and abundances observed in 2008 over the Chukchi shelf agree with the high productivity commonly observed in summer across the shelf (Hameedi, 1978; Cota et al., 1996; Sakshaug, 2004; Hill and Cota, 2005). The high contribution of large cells, such as diatoms Chaetoceros sp., or Fragilaria sp., Cylindrotheca sp. and dinoflagellates during the low sea ice summer 2008 are comparable to those of more icy years in the marginal Barents and Chukchi seas dominated by the centric diatoms Chaetoceros furcillatus, Thalassiosira sp., the pennate diatoms Cylindrotheca closterium, Fragilariopsis oceanica and dinoflagellates (Hill et al., 2005; Sukhanova et al., 2009; Poulin et al., 2011). Dominance of nanoplankton in the surface shelf waters in 2008, likely reflect post-bloom conditions as also reported by Hodal and Kristiansen (2008) in the Barents Sea.

In contrast to the shelf, phytoplankton assemblages in summer 2008 in the oligotrophic Canadian basin point to high abundances of prasinophytes such as Micromonas sp. Previous phytoplankton observations during more icy years highlighted abundant prasinophytes better adapted to low nutrient concentrations (Lovejoy et al., 2006, 2007). Also remarkable is the dominating nanoplankton biomass in all of the three offshore ice areas (IFB, MIZ and HIB). Another notable feature is the abundance of pelagic diatoms (Minidiscus sp., Navicula sp. and Chaetoceros sp.) in summer 2008 at the higher most latitudes of the Canadian basin $\left(>80^{\circ} \mathrm{N}\right)$. High diatom abundances have been previously reported close to the pole covered by ice throughout the year, mainly as sea ice-associated algae such as the centric diatoms Melosira arctica (Booth and Horner, 1997; Gradinger, 1999; Melnikov et al., 2002). During summer 2008 and probably because of the sea-ice shrinking close to the pole, taxonomic observations indicate that sea ice-associated diatom species could have been replaced in part by pelagic diatoms.

In icier past summers, highest production occurred in spring as "ice edge blooms" over the shelves (Sakshaug and Skodjal, 1989; Luchetta et al., 2000; Tremblay et al., 2006; Perrette et al., 2011) and was mainly composed of centric diatom genera Chaetoceros sp., Thalassiosira sp. and prymnesiophyte Phaeocystis pouchetii (Wassmann et al., 1999). In 2008, high abundance and biomass of centric diatoms Chaetoceros and Fragilaria sp. and typical polar species Phaeocystis pouchetii were found at the ice edge over the shelf. The genus Thalassissira sp. was mainly observed south of the shelf, an area influenced by the Pacific inflow in 2008. High biomasses dominated by diatoms (Nitztschia sp. and Fragilariopsis sp.) and haptophytes were also observed in the marginal ice zone (MIZ) of the Canadian basin at higher latitudes $\left(77-80^{\circ} \mathrm{N}\right)$ than during icier years during which the MIZ was never observed further north than the continental shelves.

Overall, in summer 2008, the phytoplankton species and main functional groups are similar to those described earlier in the Pacific Arctic but their distributions are somewhat different. Because of lack of data, the comparison is weak and limited in the Arctic Ocean, especially in the central Arctic basins. There was no previous pigment data over the Canadian Arctic basin. The only taxonomic data from this region, before the extensive melting occurring since 2007, have been produced from the Arctic Ocean Section (R/V AOS) cruise in July-August 1994 (Booth et al., 1997; Gosselin et al., 1997). We, thus, compared phytoplankton distributions from the Chukchi Borderland and the Mendeleev Abyssal Plain during a summer of intense ice melting 2008 (R/V CHINARE) and the icier summer 1994 (R/V AOS). The 1994 and 2008 cruises have similar ship tracks between 


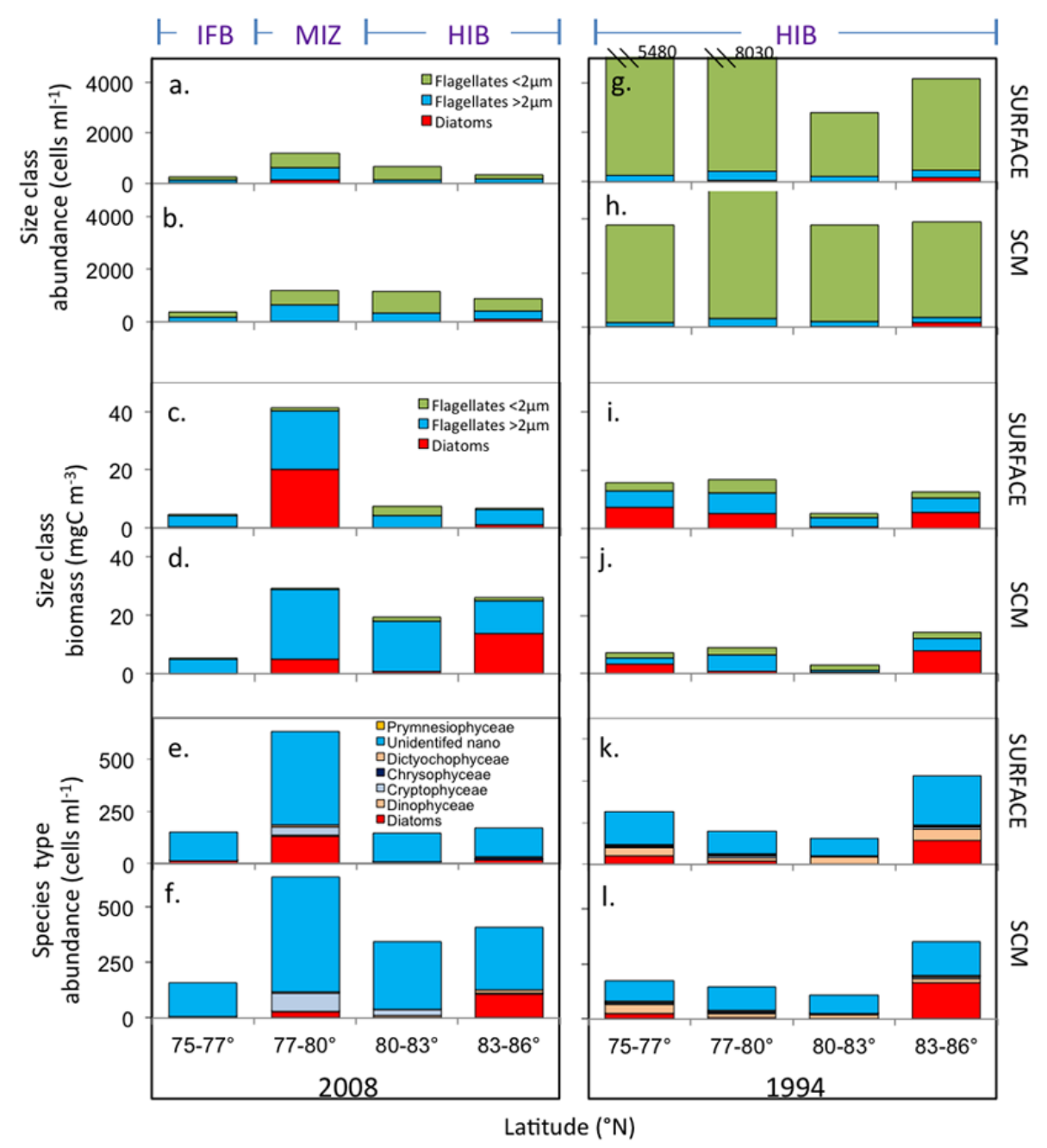

Fig. 7. Comparison of the taxonomic distribution of phytoplankton obtained during the R/V CHINARE 2008 (left panels) and R/V AOS 1994 (right panels) cruises. The phytoplankton abundance $(\mathbf{a}, \mathbf{b}, \mathbf{g}, \mathbf{h})$ and biomass $(\mathbf{c}, \mathbf{d}, \mathbf{i}, \mathbf{j})$ of three size classes: flagellates $(<2 \mu \mathrm{m})$, flagellates $(>2 \mu \mathrm{m})$ and diatoms and the abundances of the main seven planktonic taxa $(\mathbf{e}, \mathbf{f}, \mathbf{k}, \mathbf{l})$ are averaged over four latitude ranges in surface and at the SCM.

65 and $80^{\circ} \mathrm{N}$, but different north of $80^{\circ} \mathrm{N}$ (Fig. 1b). Sampling was performed west of the Mendeleev Abyssal Plain $\left(\sim 175^{\circ} \mathrm{W}\right)$ in 1994 and east of the Mendeleev Abyssal Plain during the 2008 cruise. The $\mathrm{Chl} a$ concentration maximum in the Arctic follows the sea ice retreat and is typically observed between May and June over the Chukchi shelf (Longhurst, 1995; Wang et al., 2005) and probably later over the Canadian basin. Both R/V AOS and R/V CHINARE cruises were carried out during post-bloom conditions.

Phytoplankton communities in 2008 show differences in term of geographical distribution, abundance and species dominance as compared to 1994. At all stations considered, the average standing stock of diatoms and two size classes of flagellates $(<2 \mu \mathrm{m}$ and $>2 \mu \mathrm{m})$ was drastically lower in 2008 (Fig. 7a, b) than in 1994 (Fig. 7g, h). Differences in cell numbers were mainly attributed to a ten times lower abundance of picoplankton in surface and sub-surface wa- ters in 2008. While in 1994, picoplankton accounted for $96 \%$ of the total abundance (Fig. $7 \mathrm{~g}, \mathrm{~h}$ ) and $20 \%$ of the total biomass (Fig. 7i, j); it represented only $42 \%$ of total abundances (Fig. 7a, b) and $5 \%$ of the total biomass in 2008 (Fig. 7c, d). The drastic picoplankton decrease in 2008 could result from the sensitivity of this group to photo-inhibition (Finkel et al., 2010; Key et al., 2010) caused by sea ice thinning and removal of snow deposited on sea ice. Moreover, the dinophyceae Gymnodinium sp., abundant in $1994(\sim 30$ cell $\mathrm{ml}^{-1}$; Fig. $\left.7 \mathrm{k}, \mathrm{l}\right)$ was an order of magnitude lower in 2008 (Fig. 7e, f).

Despite reduced total abundances in 2008 , regions such as the MIZ over the Canadian basin $\left(77-80^{\circ} \mathrm{N}\right)$ showed phytoplankton biomasses (Fig. 7c, d) three times higher than in 1994 (Fig. 7i, j) due to a higher abundances of unidentified nanoplankton, cryptophytes and diatoms in 2008 (Fig. 7e, f) than in 1994 (Fig. 7k, 1). In contrast, in 2008 the IFB 
$\left(75-77^{\circ} \mathrm{N}\right)$ was lower in phytoplankton abundance, biomass and diversity than during 1994 ice-covered conditions. In 1994, phytoplankton biomass at this latitude $\left(75-77^{\circ} \mathrm{N}\right)$ was mainly composed of diatoms (45\%), large flagellates $(30 \%)$ and picoplankton $(25 \%)$. In contrast in 2008, the biomass was 2-3 times lower and largely dominated by unidentified nanoflagellates (>90\%) both in surface and SCM while diatoms and dinoflagellates abundances was 10 and 20 times lower than in 1994. In the northern part of the Canadian basin $\left(83-86^{\circ} \mathrm{N}\right)$ diatom abundances were surprisingly high $\left(\sim 100\right.$ cells $\left.\mathrm{ml}^{-1}\right)$ as well in SCM in 2008 (Fig. 7f) than in surface and SCM in 1994 (Fig. 7k, 1). The nutrient sources sustaining these large taxa are still unknown and further studies on the river or multi-year sea ice nutrient budget in the central Arctic should provide some answers.

Differences between phytoplankton distributions between 1994 and 2008 could come in part from the microscopic countings. Settling chambers and inverted light microscopy (Utermöhl, 1931) were used for cell enumerations for the 1994 samples while normal light microscopy was used in 2008. Moreover, different transfer functions were used to derive carbon biomass from phytoplankton biovolumes. Equations were based on Strathmann (1967) for 1994 samples and on Mender-Deuen and Lessard (2000) for those collected in 2008. Comparison of both methods on 2008 samples revealed that picoplankton is overestimated by a factor 6 and nanoplankton underestimated by $20 \%$ with the Strathmann method. Nevertheless, the bias resulting from the selected method affects the biomass calculations, but cannot explain the difference in cell abundances between the two years.

Therefore, despite methodological biases, sea ice retreat and melting could be a determinant parameter in the different phytoplankton pattern between 1994 and 2008. Sea ice retreat over the Canadian basin could locally increased phytoplankton abundances due to the presence of an offshore MIZ. But, the total disappearance of the sea ice cover in the south of the Canadian basin likely explain the phytoplankton impoverishment and decrease in phytoplankton abundance and Chl $a$ biomass of less large cells (diatoms and dinoflagellates) and picoplankton and higher production of nanoplankton (chrysophytes and prymnesiophytes).

\subsection{Role of the environmental conditions on the 1994 and 2008 phytoplankton distributions}

What environmental parameters could explain such differences in phytoplankton spatial distributions between 1994 and 2008? The more remarkable environmental change between the two years was the sea ice coverage (Fig. 8a, Table 3). In 1994, all offshore stations were sampled under thick ice cover ( $>90 \%$ ) while in 2008 , the ice retreat above the Canadian basin reached $77^{\circ} \mathrm{N}$ and allow for the determination of three zones, the IFB $\left(74-77^{\circ} \mathrm{N}\right)$, the MIZ (77$\left.80^{\circ} \mathrm{N}\right)$ and the HIB $\left(80-86^{\circ} \mathrm{N}\right)$. This exceptional ice melting resulted in the a surface salinity decrease by 3 units (Fig. 8c,
Table 3. Means ( \pm SD) of several physical and chemical parameters in the Pacific Arctic $\left(75\right.$ to $86^{\circ} \mathrm{N}$ ) during the 1994 and 2008 cruises. The significance ( $p$ ) of the observed differences (Student's $t$-test) is shown at the confidence level $* * p<0.001$; ns: not significant.

\begin{tabular}{lrrr}
\hline Variable & 2008 & 1994 & $p$ \\
\hline Ice $(\%)$ & $21.5 \pm 28.3$ & $95.8 \pm 4.2$ & $* *$ \\
Temperature $\left({ }^{\circ} \mathrm{C}\right)$ & $-1.1 \pm 0.5$ & $-1.6 \pm 0.1$ & $* *$ \\
Salinity (psu) & $28.4 \pm 1.7$ & $31.3 \pm 0.7$ & $* *$ \\
SFL (m) & $37.7 \pm 16.0$ & $20.2 \pm 13.3$ & $* *$ \\
SI $\left(\mathrm{kg} \mathrm{m}^{-3}\right)$ & $3.8 \pm 1.3$ & $2.6 \pm 0.8$ & $* *$ \\
Zeu (m) & $61.1 \pm 19.2$ & $64.2 \pm 12.7$ & $\mathrm{~ns}$ \\
Nutricline (m) & $40.3 \pm 17.7$ & $23.5 \pm 10.8$ & $* *$ \\
SCM depth (m) & $37.9 \pm 11.5$ & $14.2 \pm 7.1$ & $* *$ \\
\hline
\end{tabular}

SFL: surface fresh layer; SI: stratification index; Zeu: euphotic depth; SCM: surface chlorophyll maximum.

Table 3) and a thickening of the surface fresh layer (SFL) by a factor 2 (Fig. 8d) over the Canadian basin as compared to year 1994 (Fig. 8d, Table 3). The freshening of the surface layer leads to a stronger stratification as shown by the correlation between the salinity and the stratification index $(\mathrm{SI})\left(R_{\text {Salinty, SI }}=-0.87\right)$. Stronger stratification prevents the supply of deep-water nutrients while the establishment of a thick SFL deepens the nitracline (Fig. 8e; $R_{\mathrm{SFL}}$, Nitracline $=0.67$ ). The observed deepening of the nutricline agrees with previous observations from the Canadian Basin (Mc Laughlin and Carmack, 2010). The decrease of the nutrient availability in surface waters subsequent to a deeper nitracline led to lower surface Chl $a$ concentration ( $\left.R_{\text {Nitracline, Surf } \mathrm{Chl} a}=-0.62\right)$ and a deepening of the SCM (Fig. 8f; $R_{\text {Nitracline, DepthSCM }}=0.67$ ). Since the euphotic depth did not change much between 1994 and 2008 (Table 3), deepening of the SCM in 2008 is likely responsible for less productive phytoplankton communities due to light attenuation. The strong freshening and associated deep nutricline observed in the IFB in 2008 (Fig. 8c, d, e) was associated with lower abundances of diatoms and dinoflagellates (Fig. 7e, f) and a deeper SCM (Fig. 8f, Table 3) than in the same areas under heavy ice conditions in 1994 (Fig. 7k, 1). The nanoplankton dominated the phytoplankton assemblages in the IFB suggesting a better adaptation to the low nutrients and light occurring in this region. Even if the vertical stratification resulting from freshening reduces surface nutrient availability, part of the nutrient depletion observed in the IFB might be attributed to consumption by phytoplankton.

In contrast to IFB, a weak freshening (Fig. 8c, d) and a shallow nutricline (Fig. 8e) associated with the formation of an offshore MIZ due to extensive withdrawal of sea ice in 2008, likely provided optimal conditions for diatoms and nanoplankton growth (Fig. 7c, d, e, f). These high levels of phytoplanktonic biomass in the MIZ were comparable to shelf values and could be assimilated to sea ice 


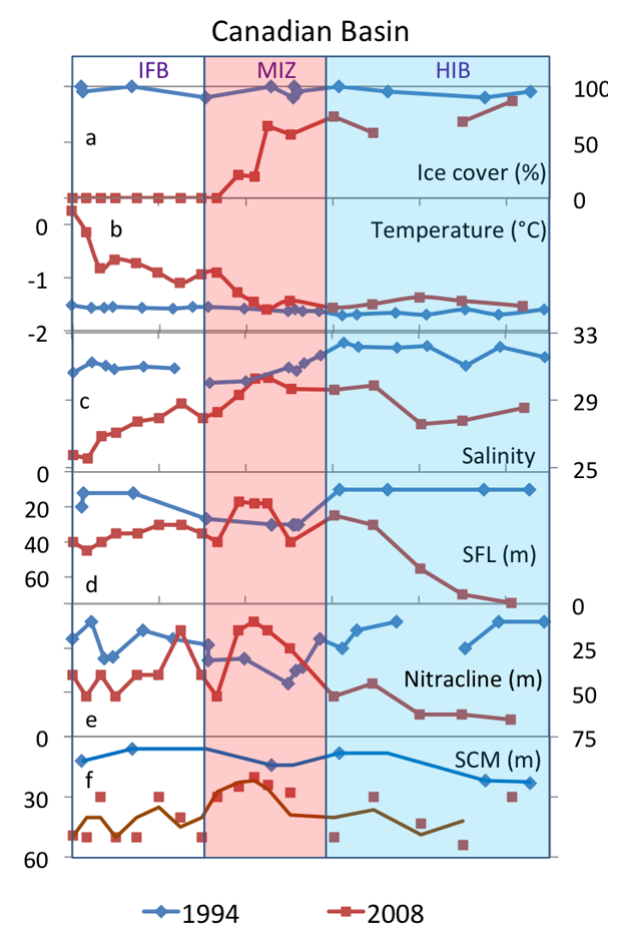

Fig. 8. Environmental parameters in surface waters and at the SCM during summer 1994 (blue bars) and 2008 (orange/brown bars) in the Canadian basin. Ice conditions labels are indicated on the top of the panels: IFB (ice-free basin), MIZ (marginal ice zone), HIB (heavy-ice basin). Ice cover in \% (a), temperature in ${ }^{\circ} \mathrm{C}(\mathbf{b})$, surface salinity (c), SFL (surface fresh layer) depth in $\mathrm{m}$ (d) nitracline in m (e) SCM (sub-surface chlorophyll maximum) depth in $\mathrm{m}$ (f) are presented for 1994 (blue lines) and 2008 (orange line).

edge blooms found in marginal Arctic seas (Luchetta et al., 2000; Hill et al., 2005; Tremblay et al., 2006). However, species inhabiting these "offshore ice edge blooms" are composed of pennate diatoms Nitzschia sp. and Fragilariopsis sp., and the nanoplankton classes dictyochophytes and crysophytes, thus, different from species living in sea ice edge over the shelf, usually dominated by the diatoms Chaetoceros spp., Fragilaria sp. and Fragilariopsis sp. and by unidentified nanoplankton and Phaeocystis pouchetii (Alexander and Niebauer, 1981; Sukhanova et al., 2009; Seegreva et al., 2010).

Interannual variability in the hydrography, the circulation pattern and river inputs could be other causes for 19942008 phytoplankton differences. Recent studies highlighted the weak influence of McKenzie River on the pool of nutrients in the Canadian basin (Emerton et al., 2008; Simpson et al., 2008), while Russian rivers (Holmes et al., 2000; Hessen et al., 2010) should impact the phytoplankton distribution in this basin. Changes in oceanic circulation and stratification of the upper water layers associated with both sea-ice and continental ice cover reduction would be key drivers of nutri- ent availability and phytoplankton patterns in the illuminated surface layer.

\section{Conclusions}

In situ data from the R/V CHINARE 2008 cruise provide new pigment and taxonomy data in a poorly documented area of the deep central basin of the Pacific Arctic, after extreme sea ice melting in summer 2007. These results highlight significantly different phytoplankton distribution between an unusually low sea ice covered year 2008, and an icier year 1994 which can be summarised by lower abundances of large cells (diatoms and dinoflagellates) and picoplankton (prasinophytes) and more abundant nanoplankton probably due to chrysophytes and prymnesiophytes increased.

Earlier studies suggested that increase light availability due to sea ice retreat should result in increased primary production and biomass. We propose that freshening, by deepening the nutricline and reinforcing the stratification, would reduce light and nutrients availability for phytoplankton growth. The strong freshening observed in 2008 over the "ice free basin" was associated with lowest biomasses and likely promoted nanoflagellates while picoplankton, less adapted to higher and longer exposure to UV, declined in surface waters. In contrast, appearance of offshore marginal sea ice zone stimulates the production of pelagic diatoms. Finally, the strong freshening observed in HIB would be responsible for the deepening of phytoplankton communities. However, both in 1994 and 2008, relatively high diatom abundances were found in the ice covered highest latitude $\left(>83^{\circ} \mathrm{N}\right)$, but the origin of the nutrients source feeding these large taxa is still an open question.

Our in situ phytoplankton data suggest that the deep Arctic basins may evolve towards lower phytoplankton biomass and production. With the northern extension of the ice-free areas and enhanced freshening subsequent to predicted increase of sea ice melting and river discharges, impoverishment of the ice-free basins would extend northward. We can, thus, anticipate that carbon production and export might decrease in the ice-free basins and probably increase in the offshore marginal ice zone, as a consequence of changes in the phytoplankton abundance and size structure.

This study points out discrepancy between information derived from pigment analyses and microscopic counts. High fucoxanthin concentrations over the Chukchi shelf and in the surface waters of the Canadian basin suggest that besides diatoms, nanoflagellates may have contributed to the production of this pigment. Our findings also underline that pigments represent an efficient tool for the description of phytoplankton over Arctic deep basins, which are dominated by small phytoplankton poorly identified by light microscopy. Future improvement of CHEMTAX calibration for Arctic pytoplankton using in vitro experiments and in situ 
observation combining HPLC and microscopic taxonomy are needed to fully exploit the pigments data.

The R/V CHINARE cruises planned every two years in the Arctic should provide additional biogeochemical data to improve our understanding of the response of phytoplankton to on-going climate changes and get a more comprehensive picture of the Arctic ecosystem evolution in relation to ice and sea ice melting and subsequent environmental changes.

\section{Supplementary material related to this article is available online at: http://www.biogeosciences.net/9/ 4835/2012/bg-9-4835-2012-supplement.pdf.}

Acknowledgements. This research is a contribution to the Arctic Tipping Points (ATP) project (http://www.eu-atp.org) funded by FP7 of the European Union (contract \#226248) and the European programme DAMOCLES (Developing Arctic Modelling and Observing Capabilities for Long-term Environmental Studies, 2007-2010). We express our gratitude to the captain and the crew of the Chinese icebreaker R/V Xuelong for the opportunity to take part in the fieldwork in the Arctic Ocean. We thank the Second Institute of Oceanography SOA/PRC (State Oceanic Administration, China, Hangzhou) and the National Natural Science Foundation of China (NSFC, No. 41076135) for the invitation of the French scientists from the LOCEAN laboratory (UPMC - University Pierre et Marie Curie) to participate in the R/V CHINARE cruise and to support the stay of French scientists in China for the pigment analyses, but also for their warm welcome and helpfulness. We are grateful to S. Q. Gao and Y. Lu (SOA, Hangzhou, China) for their help in the nutrient analysis and sample collection, as well as professor J. P. Zhao (Ocean University China, Qingdao, China) and the Chinese and Finnish physical teams (Finnish Meteorological Institute, Helsinki) for the acquisition and transfer of the hydrological data (CTD). The Korea Research Foundation (KRF) grant funded by the Korea government (MEST) (No. 2011-0007761) provided support for S. H. Lee.

Edited by: E. Marañón

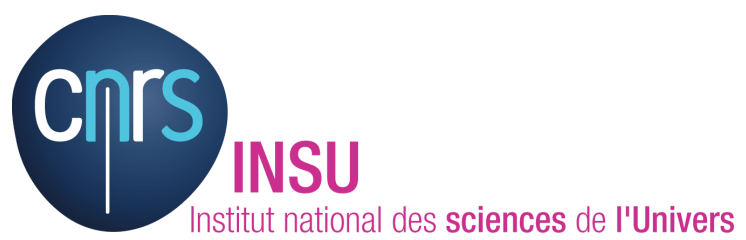

The publication of this article is financed by CNRS-INSU.

\section{References}

Alexander, V. and Niebauer, H. J.: Oceanography of the eastern Bering Sea ice-edge zone in spring, Limnol. Oceanogr., 26, 1111-1125, 1981.

Anderson, L. G., Tanhua, T., Björk, G., Hjalmarsson, S., Jones, E. P., Jutterström, S., Rudels, B., Swift, J. H., and Wahlstrom, I.:
Arctic Ocean shelf-basin interaction: An active continental shelf $\mathrm{CO}_{2}$ pump and its impact on the degree of calcium carbonate solubility, Deep-Sea Res., 1, 57, 869-879, 2010.

Arrigo, K. R., Robinson, D. H., Worthen, D. L., Dunbar, R. B., DiTullio, G. R., van Woert, M., and Lizotte, M. P.: Phytoplankton community structure and the drawdown of nutrients and $\mathrm{CO}_{2}$ in the Southern Ocean, Science, 283, 365-367, 1999.

Arrigo, K. R., van Dijken, G., and Pabi, S.: Impact of a shrinking Arctic ice cover on marine primary production, Geophys. Res. Lett., 35, L19603, doi:10.1029/2008GL035028, 2008.

Babin, S. M., Carton, J. A., Dickey, T. D., and Wiggert, J. D.: Satellite evidence of hurricane-induced phytoplankton blooms in an oceanic desert, J. Geophys. Res. Oceans, 109, C03043, doi:10.1029/2003jc001938, 2004.

Bates, N. R., Moran, S. B., Hansell, D. A., and Mathis, J. T.: An increasing $\mathrm{CO}_{2}$ sink in the Arctic Ocean dues to sea-ice loss, Geophys. Res. Lett. 23, L23609, doi:10.1029/2006GL027028, 2006.

Booth, B. C. and Horner, R. A.: Microalgae on the Arctic Ocean section, 1994: species abundance and biomass, Deep-Sea Res. 2, 44, 1607-1622, doi:10.1016/S0967-0645(97)00057-X, 1997.

Cai, W. J., Chen L., Chen, B., Gao, Z., Lee, S. H., Chen, J., Pierrot, D., Sullivan, K., Wang, Y., Hu, X., Huang, W. J., Zhang, Y., Xu, S., Murata, A., Grebmeier, J. M., Jones, E. P., and Zhang, H.: Decrease in the $\mathrm{CO}_{2}$ uptake capacity in an ice-free Arctic Ocean basin, Science, 329, 556-559, doi:10.1126/science.1189338, 2010 .

Carmack, E. C. and Chapman, D. C.: Wind-driven shelf/basin exchange on an Arctic shelf: The joint roles of ice cover extent and shelf-break bathymetry, Geophys. Res. Lett., 30, 1778, doi:10.1029/2003GL017526, 2003.

Carmack, E. and Wassmann, P.: Food webs and physical-biological coupling on pan-Arctic shelves: Comprehensive perspectives, unifying concepts and future research, Prog. Oceanogr., 71, 446477, doi:10.1016/j.pocean.2006.10.004, 2006.

Carmack, E. C., Macdonald, R. W., and Jasper, S.: Phytoplankton productivity on the Canadian Shelf of the Beaufort Sea, Mar. Ecol. Prog. Ser., 277, 37-50, 2004.

Comeau, A. M , Li, W. K. W., Tremblay, J.-E., Carmack, E. C., and Lovejoy, C.: Arctic Ocean Microbial Community Structure before and after the 2007 Record Sea Ice Minimum, PLoS ONE, 6, e27492, doi:10.1371/journal.pone.0027492, 2011.

Comiso, J. C., Parkinson, C. L., Gersten, R., and Stock, L.: Accelerated decline in the Arctic sea ice cover, Geophys. Res. Lett., 35, L01703, doi:10.1029/2007GL031972, 2008.

Cota, G. F., Pomeroy, L. R., Harrison, W. G., Jones, E. P., Peters, F., Sheldon, W. M., and Weingartner, T. R.: Nutrients, primary production and microbial heterotrophy in the southeastern Chukchi Sea: Arctic summer nutrient depletion and heterotrophy, Mar. Ecol. Prog. Ser., 135, 247-258, 1996.

Emmerton, C. A., Lesack, L. F. W., and Vincent, W. F.: Mackenzie River nutrient delivery to the Arctic Ocean and effects of the Mackenzie Delta during open water conditions, Global Biogeochem. Cy., 22, GB1024, doi:10.1029/2006GB002856, 2008.

Finkel, Z. V., Beardall J., Flynn K. J., Quiqq, A., Rees, T. A., and Raven, J. A.: Phytoplankton in a changing world: Cells size and elemental stoichiometry, J. Plankton Res., 32, 119-137, 2010.

Gordon, L. I., Jennings Jr., J. C. , Ross, A. A., and Krest, J. M.: A suggested protocol for continuous flow automated analysis of seawater nutrients (phosphate, nitrate, nitrite and silicic acid), In 
WOCE Operation Manual, WHP Office Report 90-1, WOCE Report 77, 68/91, 1-52, 1993

Gosselin, M., Levasseur, M., Wheeler P. A., Horner, R. A., and Booth, B. C.: New measurements of phytoplankton and ice algal production in the Arctic Ocean, Deep-Sea Res., 2, 1623-1644, 1997.

Gradinger, R.: Vertical fine structure of algal biomass and composition in Arctic pack ice, Mar. Biol., 133, 745-754, 1999.

Grebmeier, J. M., Overland, J. E., Moore, S. E., Farley, E. V., Carmack, E. C., Cooper, L. W., Frey, K. E., Helle, J. H., McLaughlin, F. A., and McNutt, S. L.: A major ecosystem shift in the northern Bering Sea, Science, 311, 1461-1464, 2006.

Grebmeier, J. M., Moore, S. E., Overland, J. E., Frey, K. E., and Gradinger, R.: Biological response to recent Pacific Arctic sea ice retreats, Eos. Trans. Agu., 91, 18, doi:10.1029/2010EO180001, 2010.

Hameedi, M. J.: Aspects of water column primary productivity in the Chukchi Sea during summer, Mar. Biol., 48, 37-46, 1978.

Hegseth, E. N. and Sundfjord, A.: Intrusion and blooming of Atlantic phytoplankton species in the high Arctic, J. Mar. Sys, 54, 108-119, doi:10.1016/j.jmarsys.2007.11.011, 2008.

Henriksen, P., Riemann B., Kaas, H., Sørensen, H. M., and Sørensen, H. L.: Effects of nutrient-limitation and irradiance on marine phytoplankton pigments, J. Plankton Res., 24, 835-858, 2002.

Hessen, D. O., Carroll, J., Kjeldstad, B., Korosov, A. A., Pettersson, L. H., Pozdnyakov, D., and Sorensen, K.: Input of organic carbon as determinant of nutrient fluxes, light climate and productivity in the $\mathrm{Ob}$ and Yenisey estuaries, Estuar. Coast. Shelf S., 88, 5362, doi:10.1016/j.ecss.2010.03.006, 2010.

Hill, V. and Cota, G. F.: Spatial patterns of primary production on the shelf, slope and basin of the Western Arctic in 2002, DeepSea Res., 2, 3344-3354, 2005.

Hill, V., Cota, G., and Stockwell, D.: Spring and summer phytoplankton communities in the Chukchi and Eastern Beaufort Seas, Deep-Sea Res., 2, 3369-3385, doi:10.1016/j.dsr2.2005.10.010, 2005.

Hirata, T., Aiken, J., Hardman-Mountford, N., Smyth, T. J., and Barlow, R.: An absorption model to determine phytoplankton size classes from satellite ocean colour, Rem. Sens. Environ., 112, 3153-3159, 2008.

Hirata, T., Hardman-Mountford, N. J., Brewin, R. J. W., Aiken, J., Barlow, R., Suzuki, K., Isada, T., Howell, E., Hashioka, T., Noguchi-Aita, M., and Yamanaka, Y.: Synoptic relationships between surface chlorophyll $a$ and diagnostic pigments specific to phytoplankton functional types, Biogeosciences, 8, 311-327, doi:10.5194/bg-8-311-2011, 2011.

Hodal, H. and Kristiansen, S.: The importance of small-celled phytoplankton in spring blooms at the marginal ice zone in the northern Barents Sea, Deep-Sea Res., 2, 2176-2185, 2008.

Holmes, R. M., Peterson, B. J., Gordeev, V. V., Zhulidov, A. V., Meybeck, M., Lammers, R. B., and Vorosmarty, C. J.: Flux of nutrients from Russian rivers to the Arctic Ocean: can we establish a baseline against which to judge future changes?, Water Resour. Res., 36, 2309-2320, 2000.

Jeffrey, S. W. and Vesk, M.: Introduction to marine phytoplankton and their pigment signatures, in: Phytoplankton Pigments in Oceanography, edited by: Jeffrey, S. W., Mantoura, R. F. C., and Wright, S. W., UNESCO, Paris, 37-84, 1997.
Jeffrey, S. W., Wright, S. W., and Zapata, M.: Recent advances in HPLC analysis of phytoplankton, Mar. Freshwater Res., 50, 879896, 1999.

Joo, H., Lee, S. H., Jung, S. W., Dahms, H. U., and Lee, J. H.: Latitudinal variation of phytoplankton communities in the western Arctic Ocean, Deep-Sea Res., 81-84, 3-17, doi:10.1016/j.dsr2.2011.06.004, 2011.

Key, T., McCarthy, A., Campbell, D. A., Six, C., Roy, S., and Finkel, Z. V.: Cell size trade-offs govern light exploitation strategies in marine phytoplankton, Env. Microbiol., 12, 95-104, 2010

Kwok, R. and Rothrock, D. A: Decline in Arctic sea ice thickness from submarine and ICESat records: 1958-2008, Geophys. Res. Lett., 36, L15501, doi:10.1029/2009GL039035, 2009.

Lee, S. H. and Whitledge, T. E.: Primary production in the deep Canada Basin during summer 2002, Polar. Biol., 28, 190-197, 2005.

Lee, S. H., Joo H., Liu, Z., Chen, J. F., and He, J. F.: Phytoplankton productivity in newly opened waters of the western Arctic Ocean, Deep-Sea Res., 81-84, 18-27, doi:10.1016/j.dsr2.2011.06.005, 2012.

Li, W. K., McLaughlin, F. A., Lovejoy, C., and Carmack, E. C.: Smallest algae thrive as the Arctic Ocean freshens, Science, 326, 539, doi:10.1126/science.1179798, 2009.

Longhurst, A.: Seasonal cycles of pelagic production and consumption, Prog. Oceanogr., 36, 77-167, 1995.

Lovejoy C., Massana, R., and Pedròs-Aliò C.: Diversity and distribution of marine microbial eukaryotes in the Arctic Ocean and adjacent seas, Appl. Environ. Microbiol., 2, 3085-3095, 2006.

Lovejoy, C., Vincent, W. F., Bonilla, S., Roy, S., Martineau, M. J., Terrado, R., Potvin, M., Massana, R., and Pedròs-Aliò, C.: Distribution, phylogeny, and growth of cold-adapted picoprasinophytes in arctic seas, J. Phycol., 43, 78-89, 2007.

Luchetta, A., Lipizer, M., and Socal, G.: Temporal evolution of primary production in the central Barents Sea, J. Mar. Syst., 27, 177-193, 2000.

Mackey, M. D., Mackey, D. J., Higgins, H. W., and Wright, S. W.: CHEMTAX - a program for estimating class abundances from chemical markers: Application to HPLC measurements of phytoplankton, Mar. Ecol. Prog. Ser., 144, 265-283, 1996.

Melnikov, I. A., Kolosova, E. G., Welch, H. A., and Zhitina, L.: Sea ice biological communities and nutrient dynamics in the Canada Basin of the Arctic Ocean, Deep-Sea Res., 1, 1623-1649, 2002.

Menden-Deuer, S. and Lessard, E. J.: Carbon to volume relationships for dinoflagellates, diatoms, and other protist plankton, Limnol. Oceanogr., 45, 569-579, 2000.

Napp, J. M. and Hunt Jr., G. L.: Anomalous conditions in the south-eastern Bering Sea, 1997 linkages among climate, weather, ocean, and biology, Fish. Oceanogr., 10, 61-68, 2001.

Pabi, S., van Dijken, G. L., and Arrigo, K. R.: Primary production in the Arctic Ocean, 1998-2006, J. Geophys. Res., 113, C08005, doi:10.1029/2007JC004578, 2008.

Perovich, D. K.: The changing Arctic sea ice cover, Oceanography, 24, 162-173, doi:10.5670/oceanog.2011.68, 2011.

Perrette, M., Yool, A., Quartly, G. D., and Popova, E. E.: Nearubiquity of ice-edge blooms in the Arctic, Biogeosciences, 8, 515-524, doi:10.5194/bg-8-515-2011, 2011.

Peterson, B. J., McClelland J., Curry, R., Holmes, R. M., Walsh, J. E., and Aagaard, K.: Trajectory shifts in the Arctic and Subarctic freshwater cycle, Science, 313, 1061-1066, 2006. 
Polyakov, I. V., Timokhov, L. A., Alexeev, V. A., Bacon, S., Dmitrenko, I. A., Fortier, L., Frolov, I. E., Gascard, J.-C., Hansen, E., Ivanov, V. V., Laxon, S., Mauritzen, C., Perovich, D., Shimada ,K., Simmons, H. L., Sokolov, V. T., Steele M., and Toole, J.: Arctic Ocean warming contributes to reduced polar ice cap, J. Phys. Oceanogr., 40, 743-2, doi:10.1175/2010JPO4339.1, 2010.

Poulin, M., Daugbjerg, N., Gradinger, R., Ilyash, L., Ratkova, T., and von Quillfeldt, C.: The pan-Arctic biodiversity of marine pelagic and sea-ice unicellular eukaryotes: A first-attempt assessment, Marine Biodiversity, 41, 13-28, doi:10.1007/s12526-0100058-8, 2011.

Rabe, B., Karcher M., Schauer U, Toole J., Krishfield R., Pisarev S., Kauker F., Gerdes R., and Kikuchi, T.: An assessment of panArctic Ocean freshwater content changes from the 1990's to the IPY period, Deep-Sea Res., 1, 173-185, 2011.

Rodriguez, F., Varela, M., and Zapata, M.: Phytoplankton assemblages in the Gerlache and Bransfield Straits (Antarctic Peninsula) determined by light microscopy and CHEMTAX analysis of HPLC pigment data, Deep-Sea Res., 2, 723-747, 2002.

Rysgarrd, S., Nielsen, T. G., and Hansen, B. W.: Seasonal variation in nutrients, pelagic primary production and grazing in a high-Arctic coastal marine ecosystem, Young Sound, Northeast Greenland, Mar. Ecol. Prog. Ser., 179, 13-25, 1999.

Sakshaug, E.: Primary and secondary production in Arctic Seas, in: The Organic Carbon Cycle in the Arctic Ocean, edited by: Stein, R. and Macdonald, R. W., Springer, Berlin, 57-81, 2004.

Sakshaug, E. and Skjoldal, H. R.: Life at the ice edge, Ambio, 8, 60-67, 1989.

Sergeeva, V. M., Sukhanova, I. N., Flint, M. V., Pautova, L. A., Grebmeier, J. M., and Cooper, L. W.: Phytoplankton Community in the Western Arctic in July-August 2003, Oceanology, 50, 2, doi:10.1134/S0001437010020049, 2010.

Sigman, D. and Boyle, E.: Glacial/interglacial variations in atmospheric carbon dioxide, Nature, 407, 859-869, 2000.

Simpson, K., Tremblay, J.-E., Gratton, Y., and Price, N. M.:An annual study of inorganic and organic nitrogen and phosphorus and silicic acid in the southeastern Beaufort Sea , J. Geophys. Res., 113, C07016, doi:10.1029/2007JC004462, 2008.

Slagstad, D., Ellingsen I. H., and Wassmann, P.: Evaluating primary and secondary production in an Arctic Ocean void of summer sea ice: An experimental simulation approach, Prog. Oceanogr., 90, 117-131, doi:10.1016/j.pocean.2011.02.009, 2011.

Strathmann, R. R.: Estimating the organic carbon content of phytoplankton from cell volume or plasma volume, Limnol. Oceanogr., 12, 411-418, 1967.

Sukhanova, I. N., Flint, M. V., Pautova, L. A., Stockwell, D. A., Grebmeier, J. M., and Sergeeva, V. M.: Phytoplankton of the western arctic in the spring and summer of 2002: structure and seasonal changes, Deep-Sea Res., 2, 1223-1236, doi:10.1016/j.dsr2.2008.12.030, 2009.

Sun, J. and Liu, D.: Geometric models for calculating cell biovolume and surface area for phytoplankton, J. Plankton Res., 25, 1331-1346, 2003.

Sundfjord, A., Ellingsen, I., Slagstad, D., and Svendsen, H.: Vertical mixing in the marginal ice zone of the northern Barents Sea: Results from numerical model experiments, Deep-Sea Res., 2, 2154-2168, 2008.

Tremblay, J.-E. and Gagnon, J. : The effects of irradiance and nutrient supply on the productivity of Arctic waters: a perspective on climate change, in: Influence of Climate Change on the Changing Arctic and Sub-Arctic Conditions, Proceedings of the NATO Advanced Research Workshop, edited by: Nihoul, J. C. J., Kostianoy, A. G., Liège, Belgium, 8-10 May 2008, Springer Verlag, Dordrecht, The Netherlands, 73-94, 2009.

Tremblay, J. E., Michel, C., Hobson, K. A., Gosselin, M. G., and Price, N. M.: Bloom dynamics in early-opening waters of the Arctic Ocean, Limnol. Oceanogr., 51, 900-912, 2006.

Utermöhl, H.: Neue Wege in der quantitativen Erfassung des Planktons (mit besonderer berüicksichtigung des Ultraplanktons), Verhandlungen der Internationalen Vereinigung für Theoretische und Angewandte Limnologie, 5, 567-596, 1931.

Van Heukelem, L. and Thomas, C. S.: Computer-assisted highperformance liquid chromatography method development with applications to the isolation and analysis of phytoplankton pigments, J. Chromatogr. A., 910, 31-49, 2001.

Wang, J., Cota, G. F., and Comiso, J.: Phytoplankton in the Beaufort and Chukchi Seas: distribution, dynamics and environmental forcing, Deep-Sea Res., 52, 3355-3368, doi:10.1016/j.dsr2.2005.10.014, 2005.

Wassmann, P.: Structure and function of contemporary food webs on Arctic shelves: a pan-Arctic comparison, Prog. Oceanogr., 71, 123-477, 2006.

Wassmann, P., Ratkova, T. N., Andreassen, I., Vernet, M., Pedersen, G., and Rey, F.: Spring bloom development in the marginal ice zone and the central Barents Sea, Mar. Ecol., 20, 321-346, 1999.

Wassmann, P., Duarte, C. M., Agusti, S., and Sejr, M. K.: Footprints of climate change in the Arctic marine ecosystem, Glob. Change Biol., 17, 1235-1249. doi:10.1111/j.1365-2486.2010.02311.x, 2010.

Wood, E. D., Armstrong, F. A. J., and Richards, F. A.: Determinations of nitrate in sea water by cadmium-copper reduction to nitrite, J. Mar. Biol. Assoc. UK, 47, 23-31, 1967.

Woodgate, R. A., Aagaard, K., and Weingartner, T. J.: Monthly temperature, salinity, and transport variability of the Bering Strait throughflow, Geophys. Res. Lett., 32, L04601, doi:10.1029/2004GL021880, 2005.

Wright, S. W. and Jeffrey, S. W.: Phytoplankton pigments in oceanography: guidelines to modern methods, UNESCO, Paris, 285-298, 1997.

Wright, S. W., Thomas, D. P., Marchant, H. J., Higgins, H. W., Mackey, M. D., and Mackey, D. J.: Analysis of phytoplankton of the Australian sector of the Southern Ocean: comparisons of microscopy and size frequency data with interpretations of pigment HPLC data using the "CHEMTAX" matrix factorization program, Mar. Ecol. Prog. Ser., 144, 285-298, 1996.

Yang, J., Comiso, J., Walsh, D., Krishfield, R., and Honjo, S.: Storm-driven mixing and potential impact on the Arctic Ocean, J. Geophys. Res., 109, C04008, doi:10.1029/2001JC001248, 2004.

Zhao, J. P., Weibo W., and Cooper, L.: Calculation of photosynthetically available radiation using multispectral data in the Arctic Chinese, J. Polar Sci., 21, 113-126, 2010.

Zhang, I., Spitz, Y. H., Steele M., Ashjian C., Campbell R., Berline, L., and Matrai, P.: Modeling the impact of declining sea ice on the Arctic marine planktonic ecosystem, J. Geophys. Res., 115, C10015, doi:10.1029/2009JC005387, 2010. 